\title{
خطاب التكليف من ضيق مقاصد الشريعة \\ إلى سعة مقاصد القرآن
}

بحوث ودراسات

حسن القصاب

الملخص

يسلّم هذا البحث بأن الانسان محور الاهتمام في أيّة حضارة. فيسعى، على هذا التسليم، إلى النظر في الحضارة

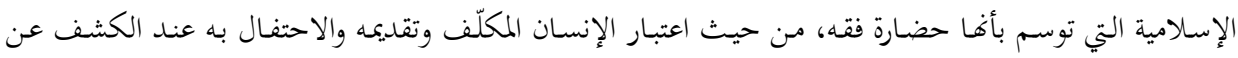

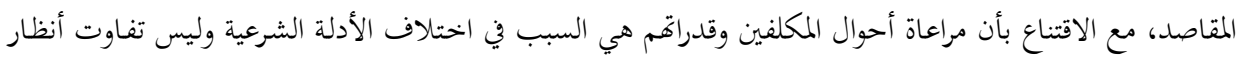

البحتهدين المقاصديين. ويسلك البحث مسلك المجادلة بين القواعد المصوغة في أحكام المكلف في علم الأصول، ومطلق

النظر المأذون به في القرآن الكريم. ويصل إلى استنتاجات مبنية على نتائج تلك المقـابلات تعود على قواعد معرفة

المقاصد بالاستفهام.

الكلمات المفتاحية: خطاب التكليف، مقاصد الشريعة، مقاصد القرآن، استقراء المقاصد.

The Discourse of "Taklif" (Religious Duty Assignment): from the Narrowness of Maqasid of Shari'ah to the Open Horizions of the Qur'anic Intents.

Hasan Al-Kassab

Abstract

This paper assumes that Man is the center of importance in any civilization. Accordingly the paper seeks to test this assumption in the Islamic civilization which is often labeled as a civilization of jurisprudence, as far as Man as a "responsible person" in jurisprudence who deserves due importance in identifying intents of shri' ah. We are convinced that conditions and capabilities of the "mukallaf" (responsible person), not the differences among scholars of Usul, are the reason behind the differences of the shar'iah evidence. The paper adopts an argumentative method that compares the rules formulated according to Maqasid of Shari'ah with the open horizons provided by the Qur'anic intents.

Keywords: Discourse of "taklif" (religious duty assignment); Intents of Islamic Law (Maqasid of shari'ah); Intents of the Gracious Qur'an; Induction of Maqasid.

* دكتوراه في أصول الفقه من جامعة محمد الخامس الرباط، وماجستير قانون الأعمال باللغة الفرنسية من جامعة دوي أنسا

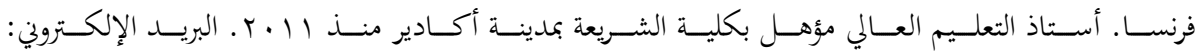

kassabhassan@hotmail.Fr

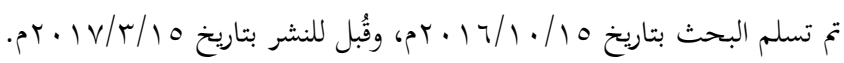




\section{مقدمة:}

مقاصد القرآن هي مطلق المقاصد والغايات والمصالح المتاحة من القرآن المعجز لكل ناظر متدبر، توافر فيه شرط فهم الخطاب. ومقاصد الشريعة هي العلمُ نفسُه المهتم بالمقاصد والغايات والمصالح التي بنيت عليها الشريعة كما توصل إليها العقل المسلم

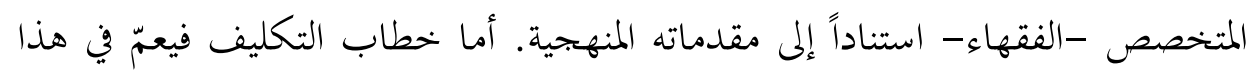

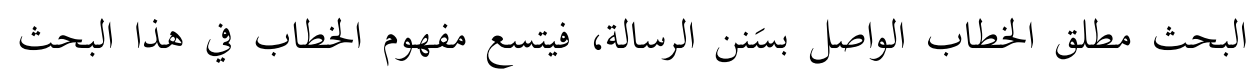
للأحكام التكليفية الخمسة، لكنه يشمل أيضا خطاب التدبر والاعتبار والاستبصار. لا يُخشى تعقيبٌ إن قيل؛ إن الحضارة نتاج تأثيرات إنسانية؛ لأنه المعنى الذي يشي

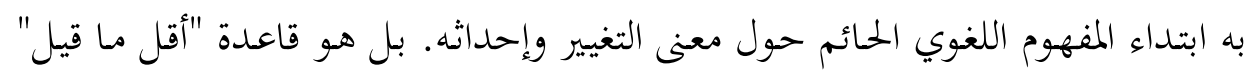

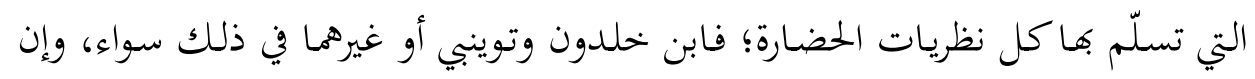
اختلف السياق وموقف النظر وعقيدة الباعث. وينبني على ذلك أن منجزات الحضارات

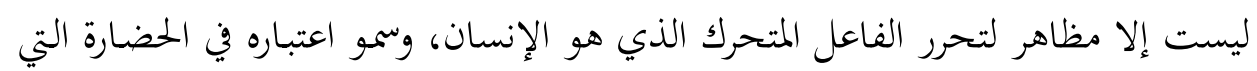
يفعل فيها وينفعل.

ولمّا كانت الحضارة الإسلامية حضارة فقه -كما عبر الجابري-، فإنه يلزم سبر هذا

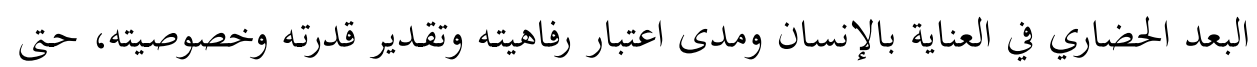

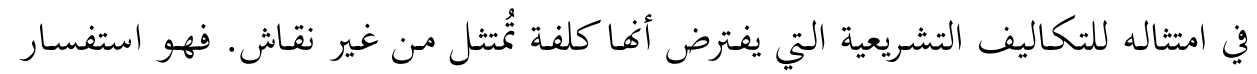

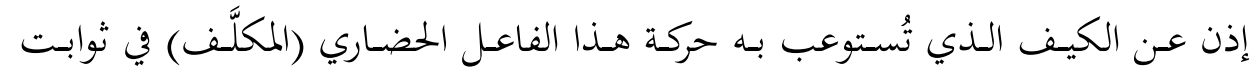

$$
\text { السياق الحضاري الإسلامي. }
$$

ولا بساطَ أمثلَ للتحقق مـن ذلك الاستيعاب مـن بساط "علم مقاصد الشريعة".

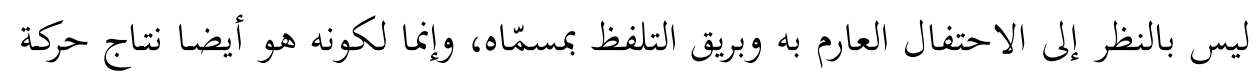

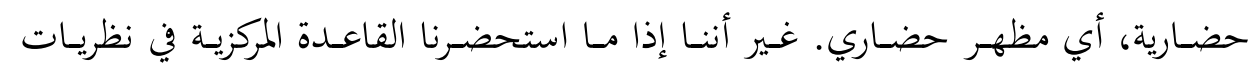
الحضارة من التمييز بين أسس الحضارة ومظاهرها، فبإن كون مقاصد الشريعة نتاجاً يحتم

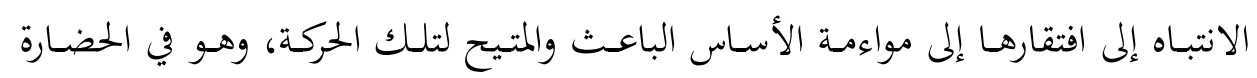


الإسلامية القرآن الكريم من غير شك؛ ليس من جهة عدم المخالفة، بل من جهة القدرة على استشراف المتاح.

ونبدأ في تتبع المواءمة بالفرضية المثبطة؛ إذ يقوى ظنٌ أن علم مقاصد الشريعة ببريق

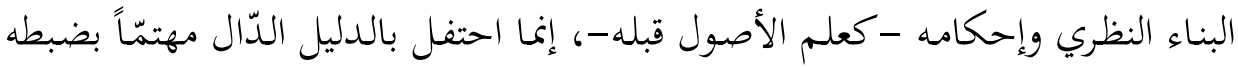

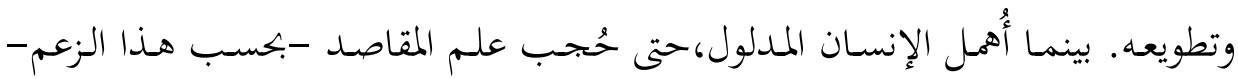

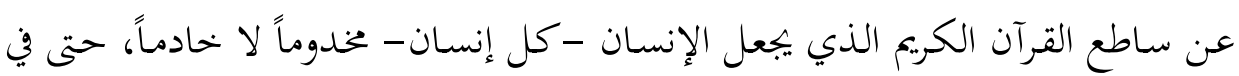
تكليفه وابتلائه.

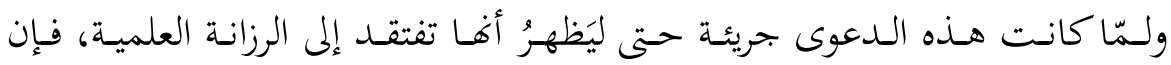

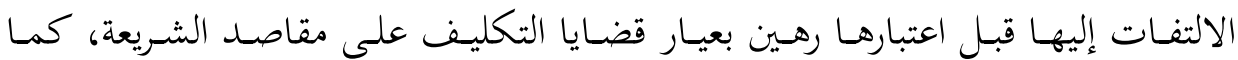
وردت في بنائها النظري مـ علم مقاصد الشريعة. كما تُعيّر على مقاصد القرآن المتاحة لكـل نظـر ولـو مـن غـير خبـير ولا مخـتص، بسـبب الإذن العـام بالتـدبر في كتـاب الله المسطور -

يساعد في هذه المحاولة وجود بناء نظري مسبق بخصوص التكليف وقضاياه، وهو ما

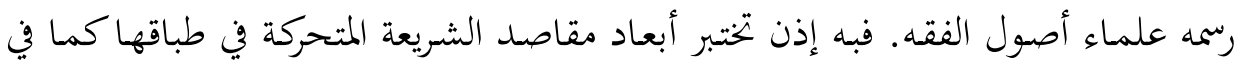

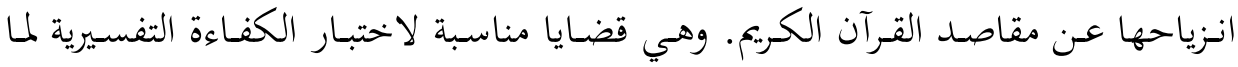

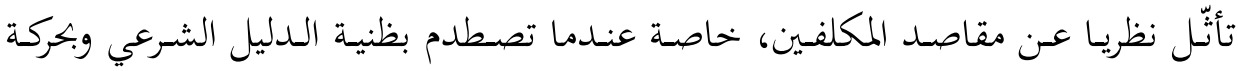
اللفظ القرآني العصي على التنميط والتقعيد والقول الواحد. لذلك تتعرض هذه المحاولة لثلاث قضايا موجِّهة: - الأولى في بعض المعالم المُشَّكة في وفاق مقاصد القرآن ومقاصد الشريعة.

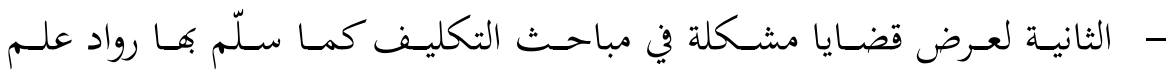
المقاصد، ثخم مقارنتها بالسعة المتاحة من مقاصد القرآن العامة.

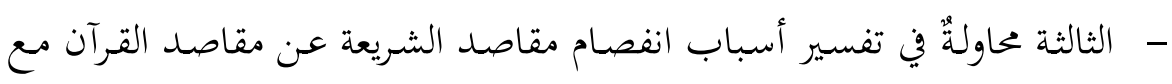
محاولة بيان ما يحجب ذاك الفصام من آفاق. 


\section{أولاً: لمحات من الوصال والفصام بين المقاصدَين}

تصـح الانطلاقـة مـن التصـيح الـذي يماثل بـين مقاصـد الشـيعة ومقاصــ القـرآن،

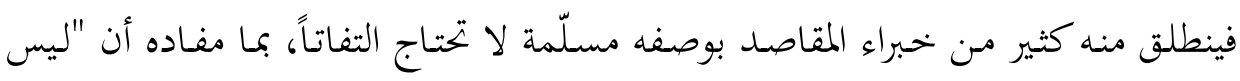
هنـاك مقاصد للشريعة سوى مقاصدِ الكتاب والسـنة." ولعله تصريح مستند إلى عبارة من الشاطبي في وصف كتابه في المقدمة بأنه: "في بيان مقاصد الكتاب والسنة" باعتماد

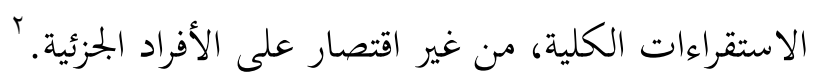

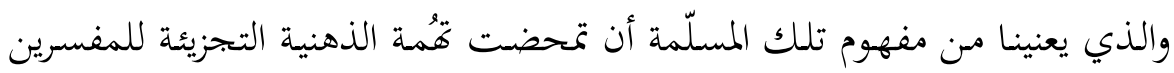

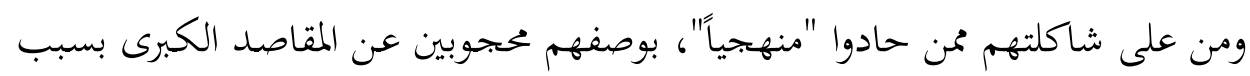

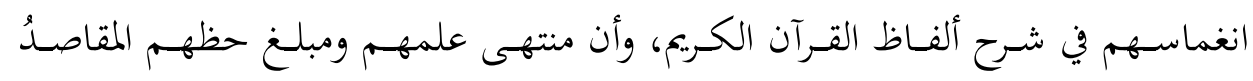

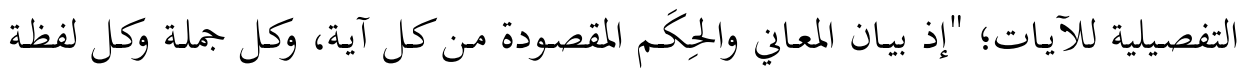
قرآنية، هو غرض المفسر من تفسيره."

لكـن لا بـأس تحققـاً أن نرجع إلى مـن عـانى ومـارس وبكـث في القـرآن عـن المقاصد استقراءً لا تنظيراً.

فهذا برهان الدين البقاعي ينبهنا أن نظن استغناء المقصد الجامع عن المقصد الجزئي؛

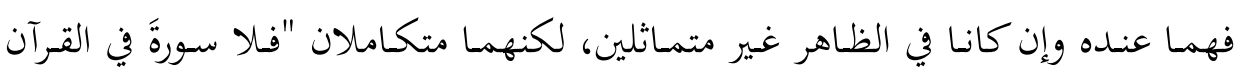

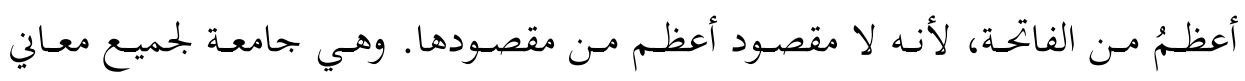
القرآن، ولا يلزم من ذلك اتحاد مقصودها مع مقصوده بالذات، وإن توافقا في المآل، فإنه

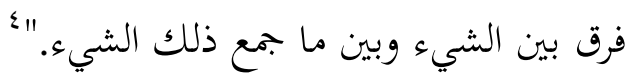

' الريسوني، أحمد. مقاصد المقاصد، الغايات العلمية والعملية لمقاصد الثريعة، بيروت: الشبكة العربية للأبحاث

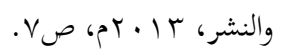
r الشاطبي، أبو إسحاق. الموافقات في أصول الشريعة، تحقيق: عبد الله دراز، بيروت: دار الكتب العلمية، طا،

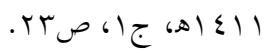

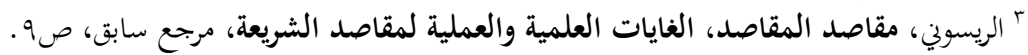

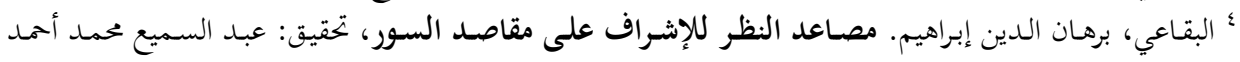

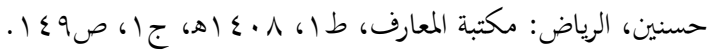


تم إن "حركة" اللفظ القرآي ما هي إلا اعتبار لحال المخاطب المكلف، ولتنوعه تنوع الخطاب؛ فلا مقاصد أسمى من تتبع هذه التصاريف وتذوق تفلتها، في كشف قواعدها

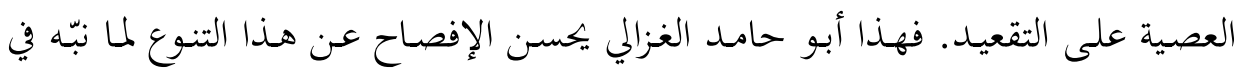

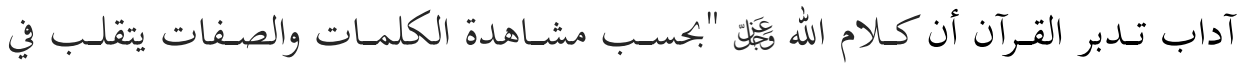
اختلاف الحالات وبحسب كل حالة منها يستعد للمكاشفة بـأمر يناسب تلك الحالة

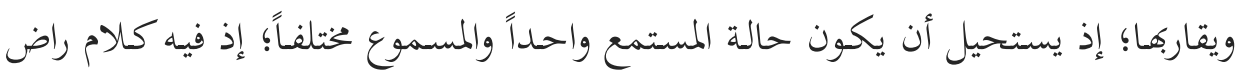
وكلام غضبان وكلام منعم وكلام منتقم وكلام جبار متكبر لا يبالي وكلام حنان متعطف لا يهمل." (1)

وعليه فإن ذلك التحقير للتفريع والتحول والتقلب في التفسير بتقلب أحوال اللفظ المعجز، هو بساط المقاصد على التحقيق. لأنه يسعى إليها بالتأسيس لا بالتحليق. بل

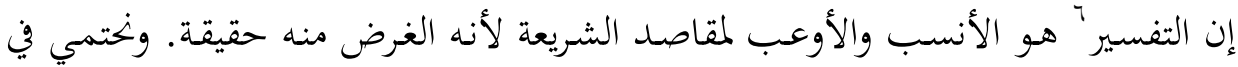
ذلكك بتصـريح قـوي للعزز ابـن عبـد السـلام حسين جعـل مـراد علـم التفسير حقيقـة هـو

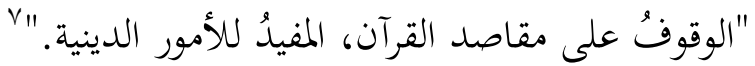

ويشجع على المضي في هـذا الاعتبـار للمخحالفـة مـا بحـده مـن رواد المقاصد القريـب عهدنا بهم -خاصة ابن عاشور ورشيد رضا-؛ فقد كشفا مقاصدَ للقرآن غير محققة في كتـب المقاصـد. ولعـل أهمها تنبهمهـا إلى سـاطع خطـاب التكليـف الجمـاعي في القـرآن الكريم، ثم تنبيهما إلى لزوم الاحتفال به أكثر مما يحتفى به خطاب الأفراد الذي لم تخرج عنه مقولات عموم الأصوليين. فالفضل في إتاحة ذاك التنبيه هو مرة أخرى لعلم التفسير؛ إذ فيه اندحرت عندهما بعض المقولات الأصولية؛ فصرحا أحياناً و أضمرا أحايين أن علم المقاصد نفسه يلزمه أن لا يذهل كذهول أصول الفقه عن آفاق التكليف الرحبة.

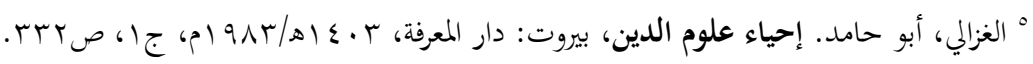

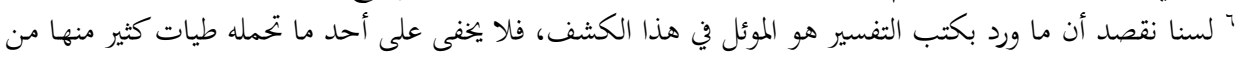

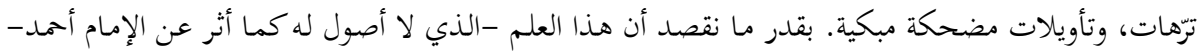

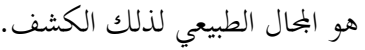

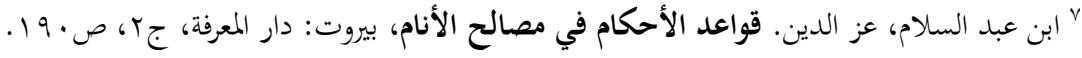


أشار محمد الطاهر بن عاشور إلى القضية في غير موضع وغير ما مرة، لكن نكتفي

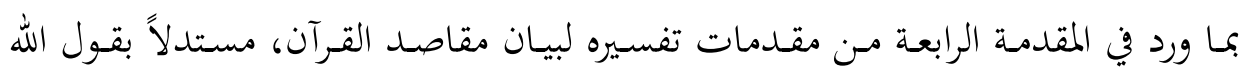

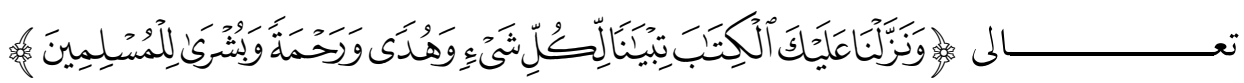

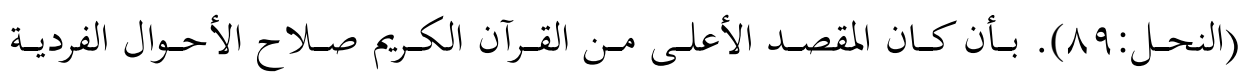

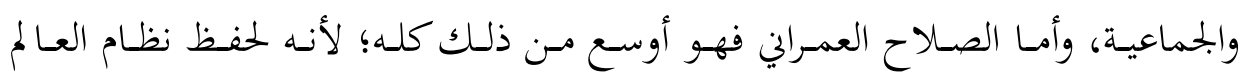

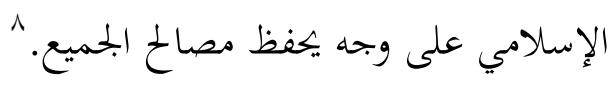

ولقد ابحلى له ذلك أيضاً في معرض بيـان مقاصد القرآن الثمانية التي انتهى إليها

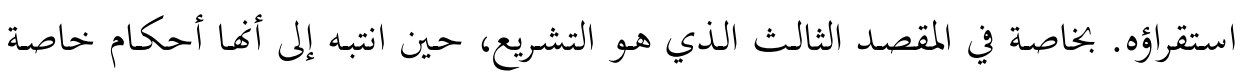

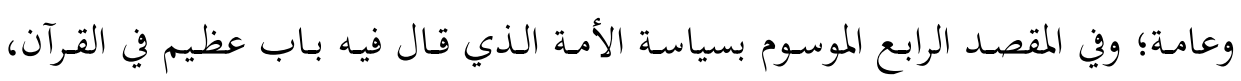
القصدُ منه صلاح الأمة وحفظ نظامها. وأيضاً في المقصد السادس الذي هو التعليم بما يناسب حالة عصر المخاطبين، وما يؤهلهم إلى تلقي الشريعة ونشرها. أما رشيد رضا؛ ففارس آخر استفاد وانتبه إلى تنوع التكليف بتنوع الخطاب وأن منه

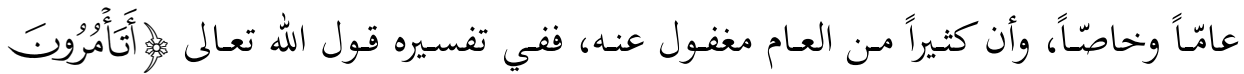

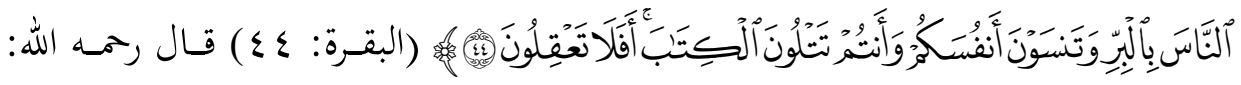

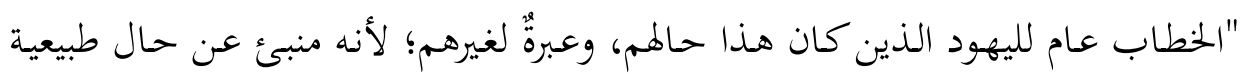

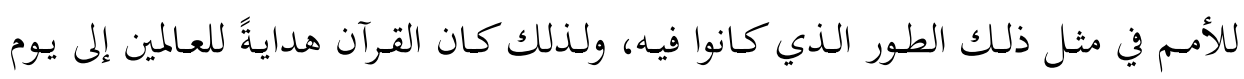
الدين، لا حكايةً تاريخ يقصد بها هجاء الإسرائيليين، فلتحاسب أمس نفسها في في أفرادها

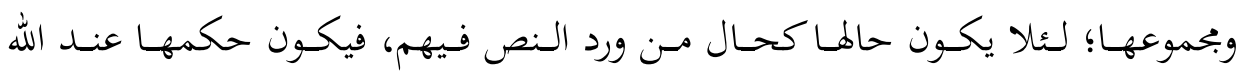

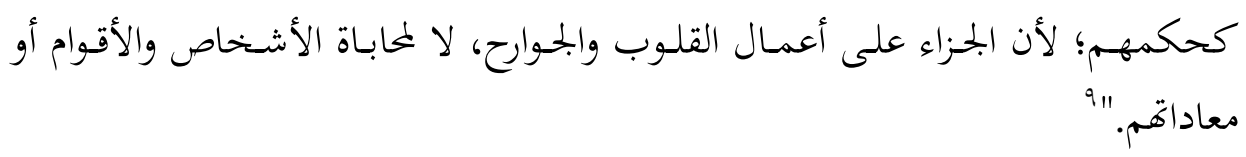

ومهما يكن من هذه الإشارات التي لم يقصد منها إلا وجه الشاهد على أن الإذن

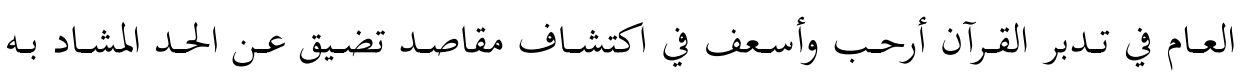

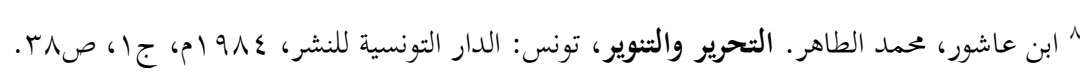

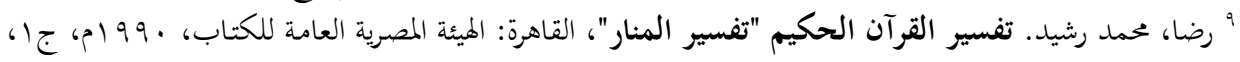




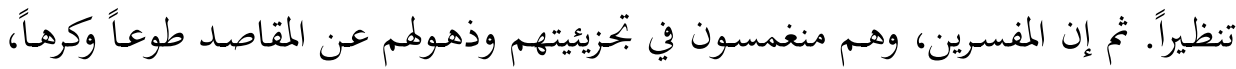

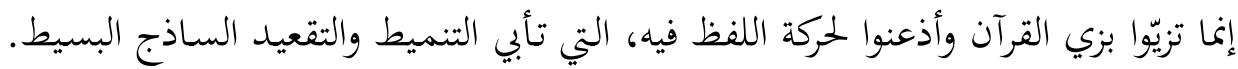

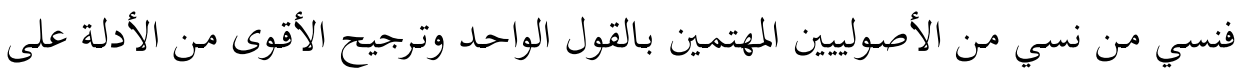
القوي، أن التفلت نفسه مقصد القرآن.

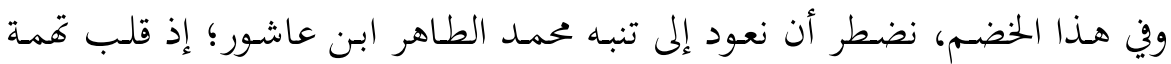

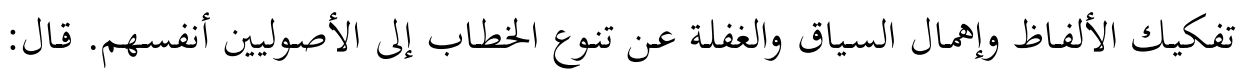

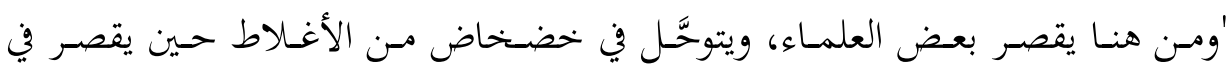

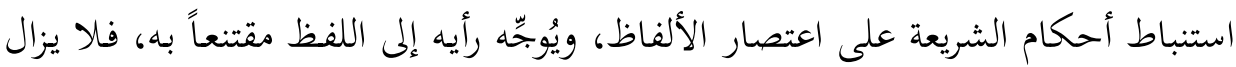

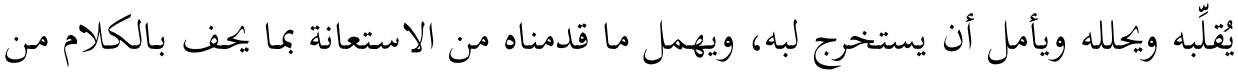

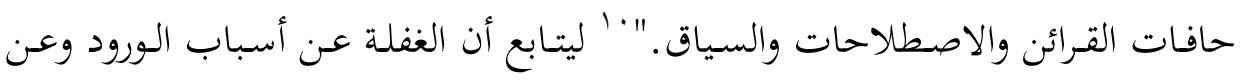

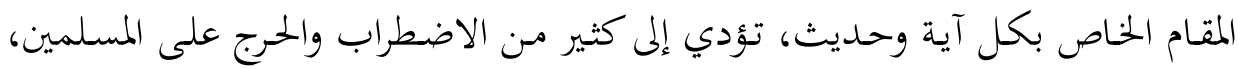

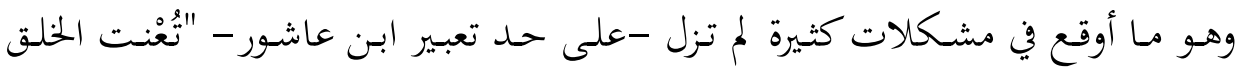

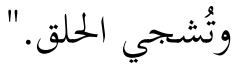

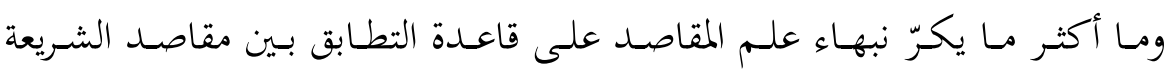

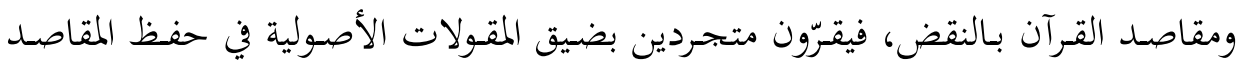

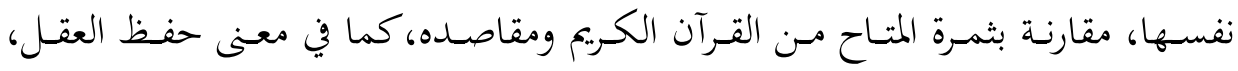

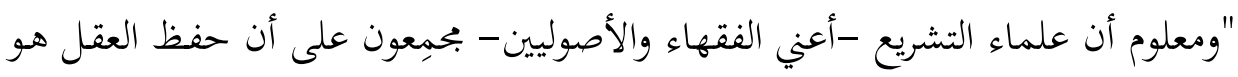

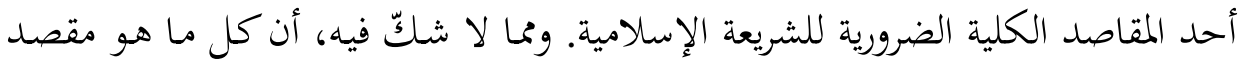

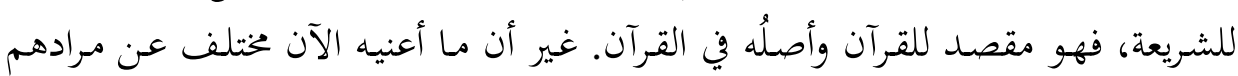

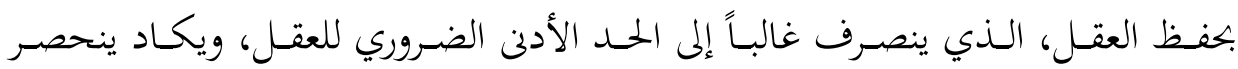

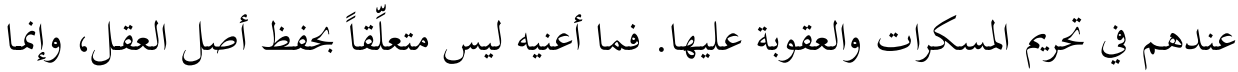
أعني: تقويم منهج التعقل والتفكير."

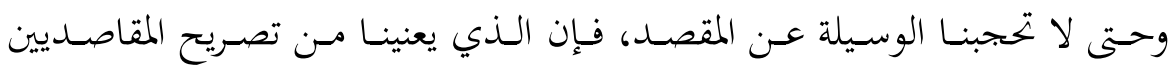

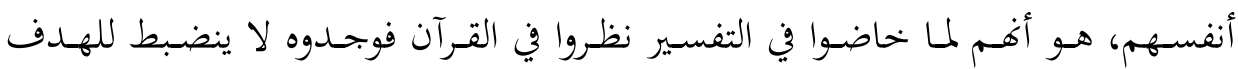

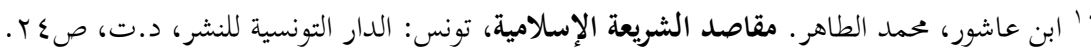

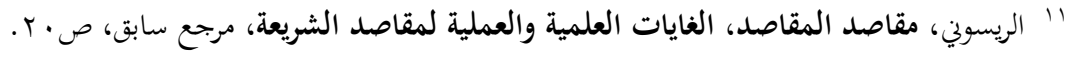


المسبق، فيصعب منه استخراج المقاصد الأصلية التي قالوا هي ما تكرر من القرآن، وأن

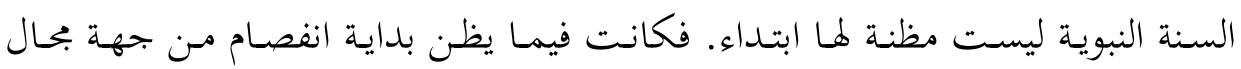
النظر

أما من جهة وسيلة النظر، فإن ما يجعل مقاصد الشريعة تنفصم عن مقاصد القرآن

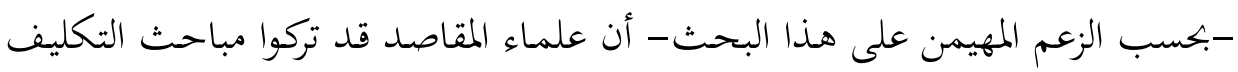
على ما دبّّه الأصوليون، وأولمم الشاطبي نفسه. فإنه كما قال محمد الفاضل ابن عاشور:

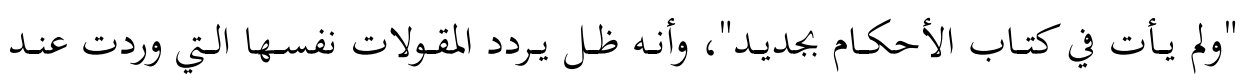

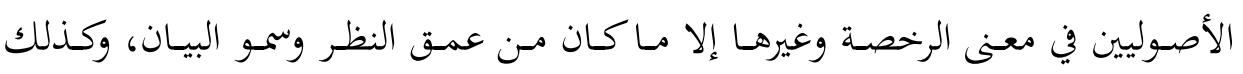

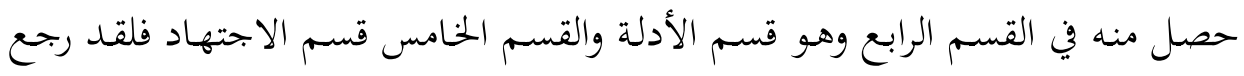

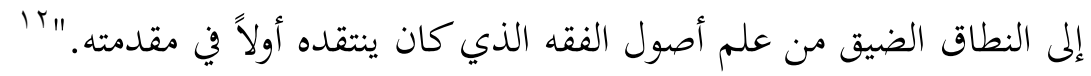
بل إن هذا الذي لحظه محمد الفاضل بن عاشور على الشاطبي يُلحظ على والده

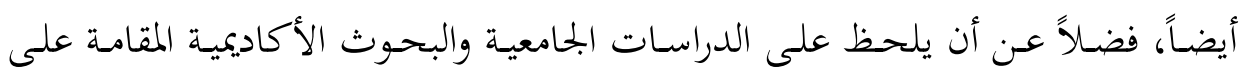

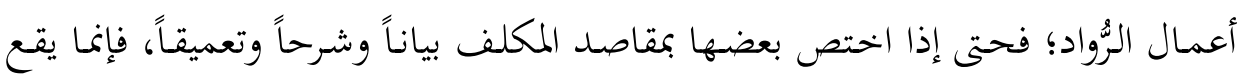

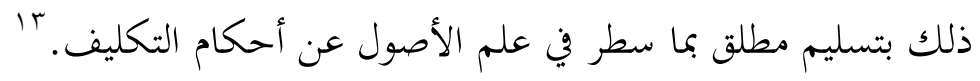

فإلى تلك المباحـث إذن، نستفسرها وقد علقنـا عليها كل اضطراب. لعل بالتمثيل ببعض قضاياها يقوى هذا الزعم الذي انطلقنا منه أو يخبو.

ثانيـاً: قضـايا مشـكلة في التكليـف بـين منطلقـات مقاصسد الشـريعة وآفـاق مقاصـد القرآن لا يُعمينا ادعاء الفصام عن الإشادة بما اختص به المقاصديّون عن عموم الأصوليين من التنبه إلى القدر المشترك في التكليف بين المقاصدَين.

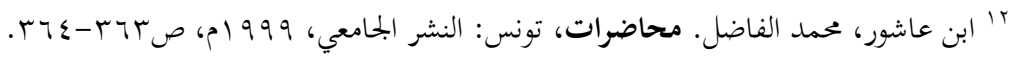

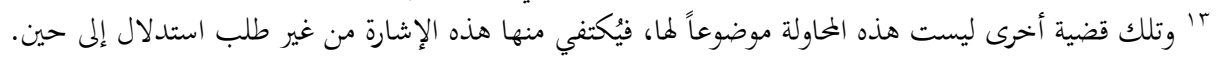


إن فقهاء المقاصـد -لله درّهـم- قـد اكتشفوا مـن القرآن أن التكليف عـام وخـاص،

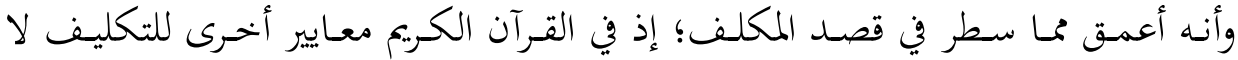
تسعها شروط التكليف الواردة عند الأصوليين، وشرط القدرة منها خاصة. فلقد وقفوا

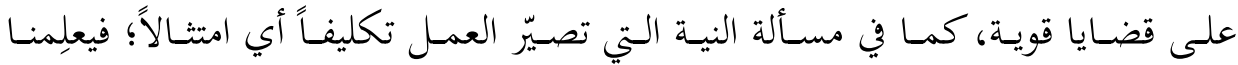

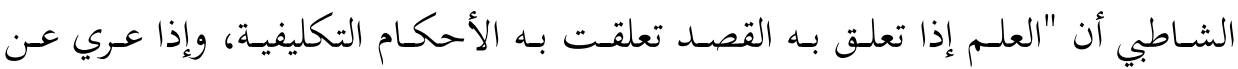

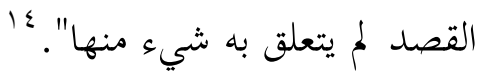

وبهذا، فالشهادة بتأثير المكلف في التكليف ناصعة، ما دام مدار التكليف على "أن

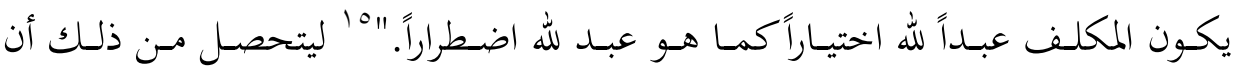

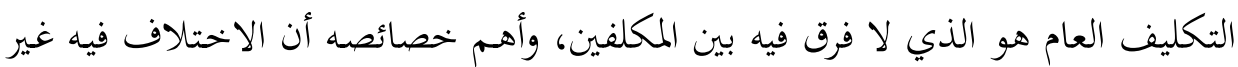

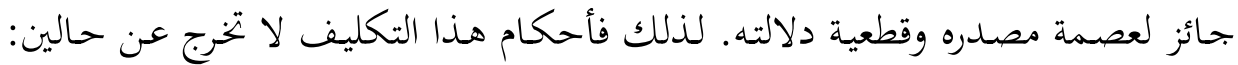

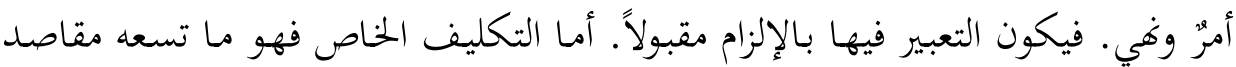

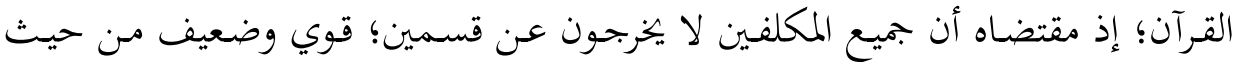

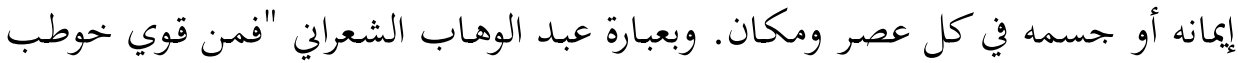

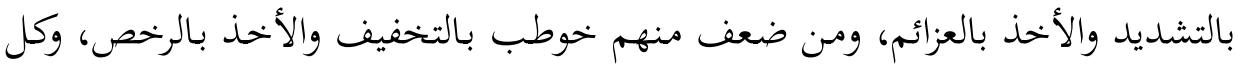

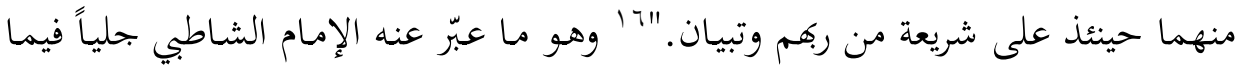

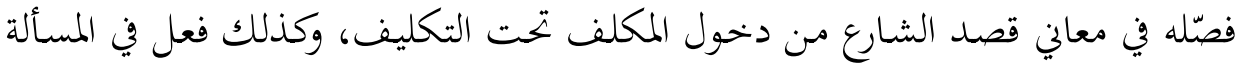

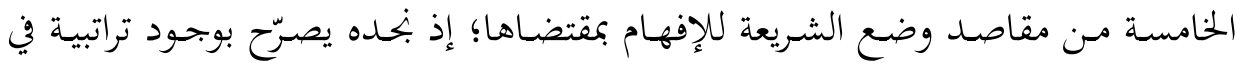

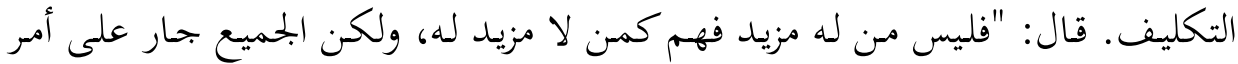

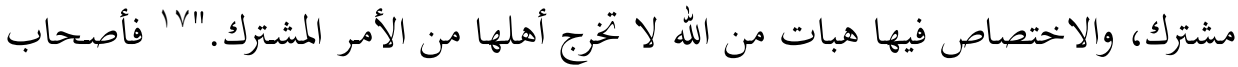

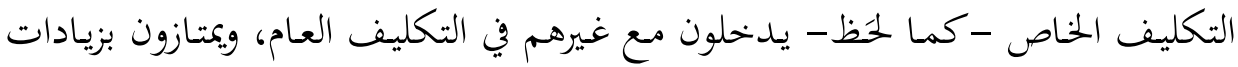

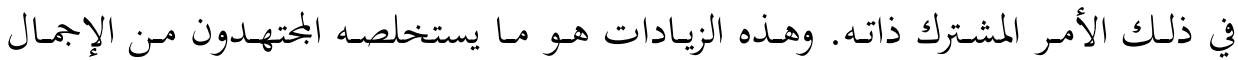

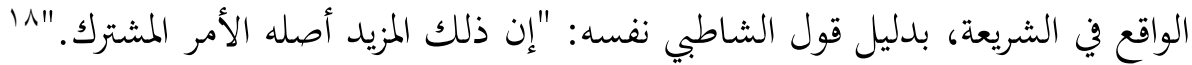

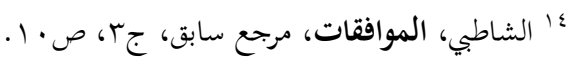

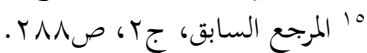

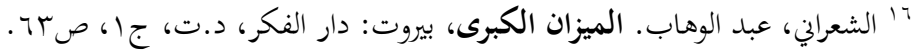

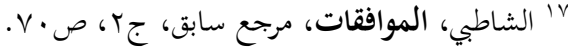
^^ المرجع السابق، الصفحة نفسها. 
ومع ذلك فإن العين لا تخطئ أن حجاب المقولات الأصولية كثيف. وأول ذلك أن

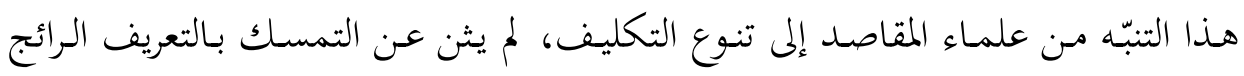
عند الأصوليين من أن "التكليف هو إلزام بما فيه كلفة." 19

فـبغض النظـر عـن تـأثر تعريـف الأصـوليين نفسـهـ بـالاختلاف اللغـوي في معـاني التكليف، فإن أول ما يثير فيه أن التعبير بالإلزام يضيق عن معاني التكليف الواسعة، لأنه

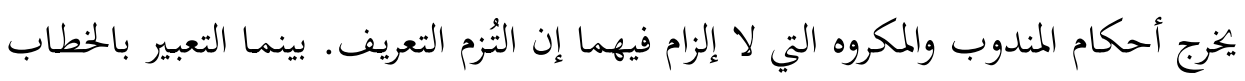

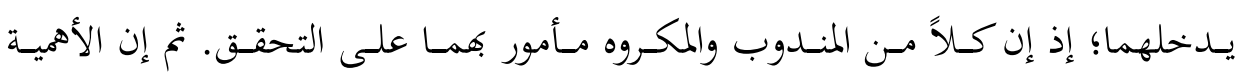
القصوى التي يكتسيها تعريف التكليف بأنه خطاب الأمر أو النهي هو إتاحته تقسيم

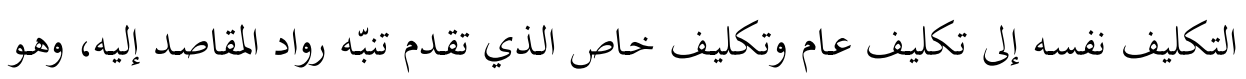
تقسيم من صميم مقاصد القرآن كما قد يتضح. وهو التقسيم الذي عبّر عنه ابن عاشور أيضا بالأحكام العامة والخاصة، فكانت تلك إضافته الخاصة في صرح علم المقاصد، وهو وهو الذي انبرى للمقاصد الجزئية للأبواب الفقهية المختلفة. وعلى كل حال، فإن الاعتبارات التي اقتضاها التمييز بين المقاصدَين في التكليف لن تتميز بوضوح إلا بالتطرق إلى مباحث شروط التكليف كما يقدمها الأصوليون، معتمدِ علماء المقاصد في مباحث التكليف التفصيلية.

\section{1 ـ شروط التكليف بين مقاصد الأصوليين ومقاصد القرآن:}

إن الإلحاح على الجانـب العملي في ادّعـاء السّعة في مقاصـد القرآن يجعلها مخالفـة حتماً لكثير من تفريعات جمهور الأصوليين، فكل الشروط التي تكلفها الأصوليون في هذا

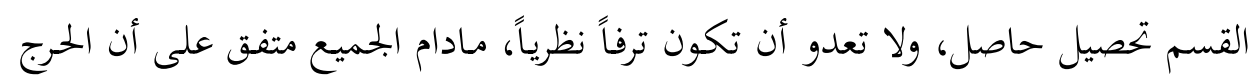

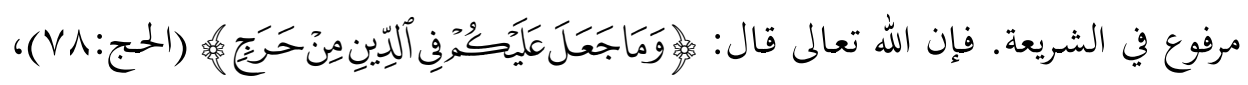

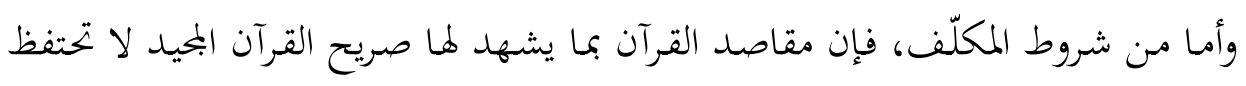
لنا فيها من بين شروط الأصوليين كلها إلا بشرطي القدرة والفهم.

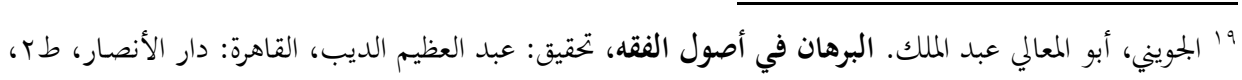

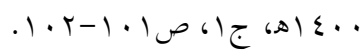


وشرط الفهـم يقصـد بـه عنــ الجميع أن المكلفف مطالب بالعمل على قـدر فهمهـ

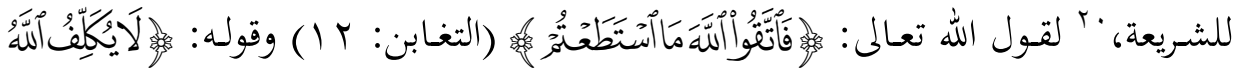

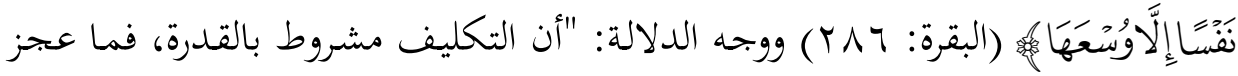
عنه المكلف من العلم -فيما عدا المعلوم ضرورة- لم يكن حكما لله في حقه، فلا يقال:

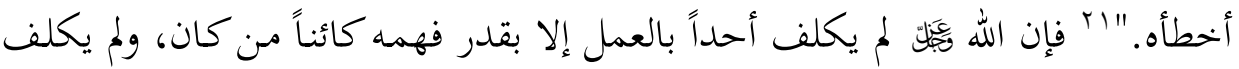
أحداً بما فهمه غيره أبداً. وعلى هذا التوسيع فإن شرط الفهم يجعله من شروط القدرة. وعليـه، فـإن القـدرة نوعـان؛ قـدرة جسـمانية وقـــرة إيمانيـة. لأن جميـع المكلفـين لا يخرجون عن قوي وضعيف من حيث إيمانه أو جسمه في كل عصر وزمان. بr فالقدرة هنا تختلف عن معناهـا في بحوث الأصوليين؛ فهم بحثوها في شروط التكليف أو مـا يسمونه

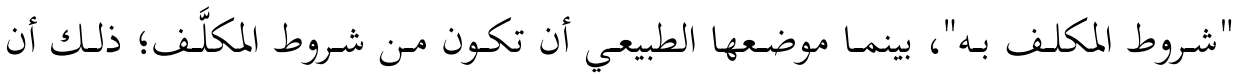
اشتراط القدرة في التكليف - كما تقدم- أمر بدهي لا فائدة علمية تحته ولا عملية. ومع ذلك فإن قيمة هذا التقسيم للقدرة لن تظهر واضحة إلا بالتطرق الى مسألة ثانية، وهي البحث في اختلال هذه الشروط نفسها، أو ما يسميه الأصوليون ب: "عوارض الأهلية". ولقد بحث جمهور الأصوليين من خحلال مبحثين؛ أولمما مبحث اختلال شروط المكلفـين، ويلخصـونه في العـوارض التي تطـرأ على الأهليـة التي جعلوهـا نـوعين سماويـة وكسبية. "r وثانيهما مبحث اختلال شروط المكلف به -وهو الأقرب لما يعنينا-؛ إذ فيه

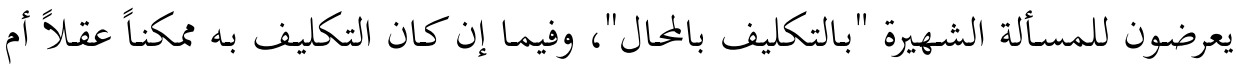
•r الشعراني، الإمام عبد الوهاب. الدرر المنثورة في زبدة العلوم المشهورة، تحقيق: عبد الحميد آل حمدان، بيروت:

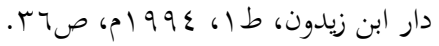

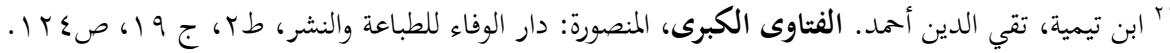

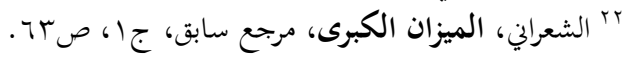

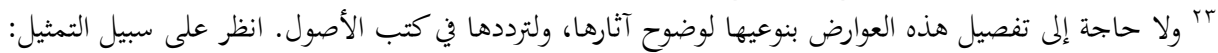

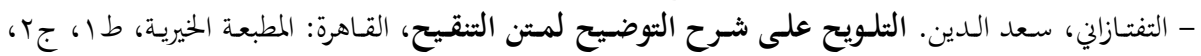
- الزبحاني، أبو المناقب محمود. تخريج الفروع على الأصول، تحقيق: محمد أديب صالح، بيروت: مؤسسة الرسالة، 
لا. ع ب وخلاصة مباحثهم فيه وما عليه أكثرهم أن التكليف بما لا يطاق غير جائز عقلاً

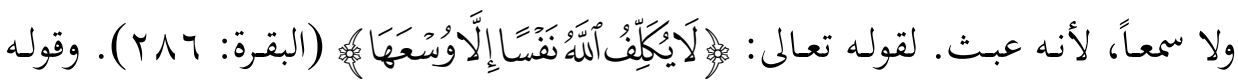

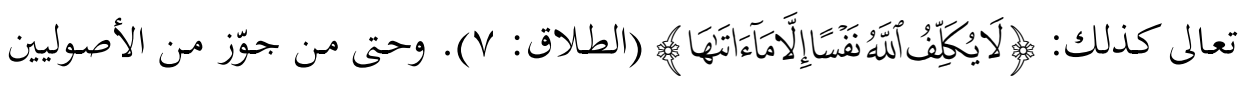
ذلك، فإنه لم يأت بما ينبغي الاشتغال بتحريره والتعرض لرده؛ ذلك أن كثيراً مـن قال

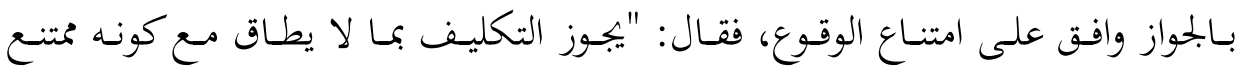

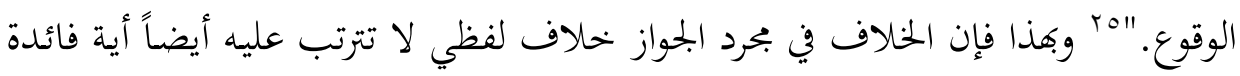
عملية.

وبملة القول، إننا نظن أن هذا الذي أطال فيه الأصوليون من تلك العوارض في رفع التكليف ليس إلا جزئيات شـاذة مقارنة مع مـا تزخر بـه الشريعة مـ تنويع في خطاب

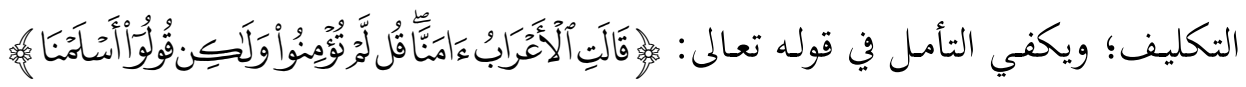

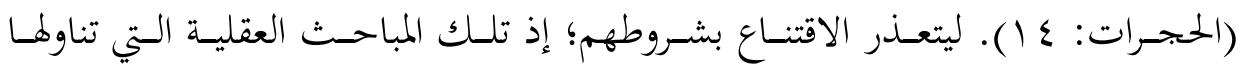
الأصوليون في عوارض الأهلية، وفي التكليف عامـة، لا تستطيع أن تفسر وقائع متكررة من فعل رسول الله ئلة وتمييزه في الخطاب بين الصحابة من جهة القدرة بنوعيها، حتى

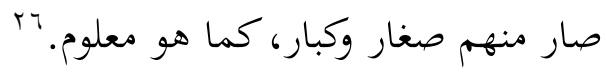

ولعل بهذا يتضح أن تنزيل التصورين -مقاصد الشريعة ومقاصد القرآن- إلى محلك

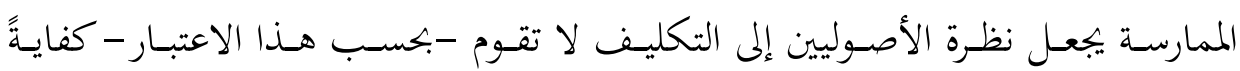
وصفية أمام الانسجام والسعة اللذين يزخر بهما خطاب الشريعة.

צُ الشوكاني، محمد بن علي. إرشاد الفحول إلى تحقيق علم الأصول، تحقيق: محمد سعيد البدري، بيروت: مؤسسة

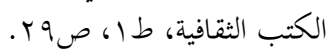
• ب المرجع السابق.

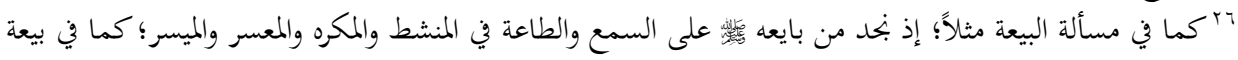

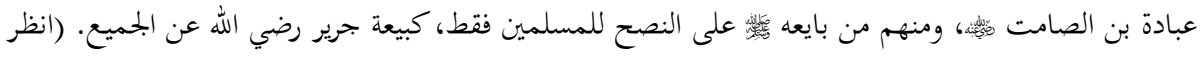

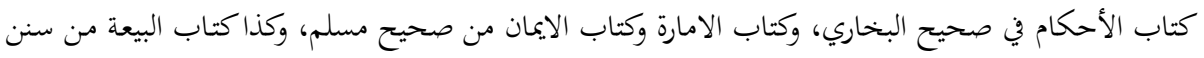

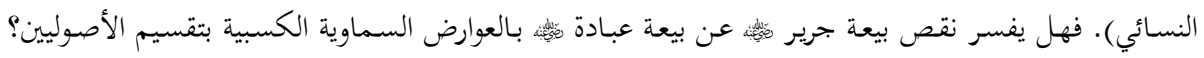

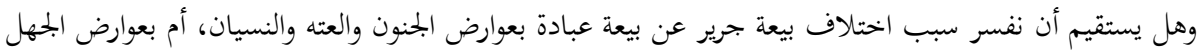
والسكر والإكراه...؟؟ أن نقريجا 
وإن شئنا مزيد سبر واستفسـار، فإنان توسيع مفهوم القـدة يهيل على قضية أخـرى مترتبّة، وهي قضية تأثير المشقة في التكليف. وبصددها نستذكر تقسيم المشـاق البـديع

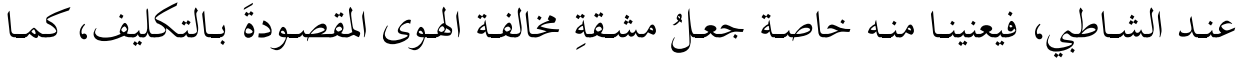

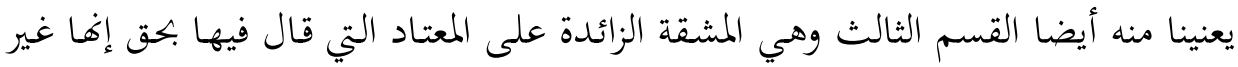

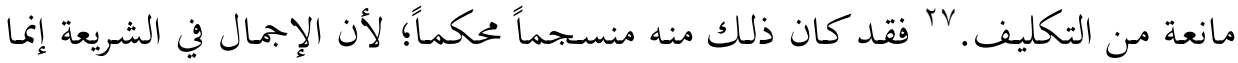

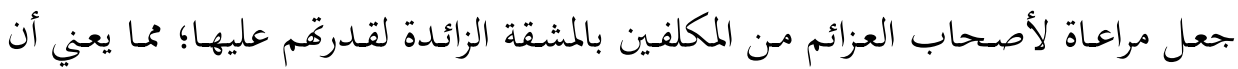

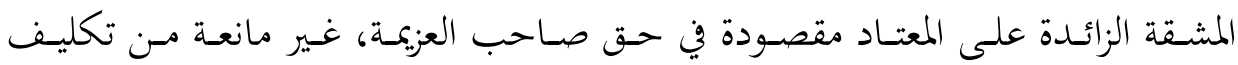
المكلف الضعيف.

ولسنا بند ذلك عند جمهور الأصوليين، إلا ماكان من إضافة خحلاف فكري نظري

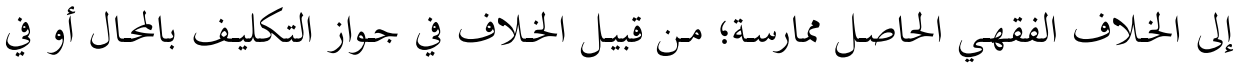
جواز تكليف الكفار بفروع الشريعة.

لكن ذلك التنبّه مرة أخرى من الشاطبي، الزائد عما عند عموم الأصوليين لا يستلزم ثمرة فارقة، وهو استدراك يلزمنا أن نعرج على مبحث متفرع منهجياً عن مفهوم القدرة،

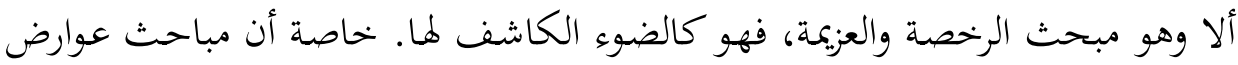
الأهلية تعد القوائم التي يقوم عليها النظر في الرخص.

\section{Y. مبحث الرخصة بين مقاصد الشريعة ومقاصد القرآن:}

تتفق أو تكاد جميع تعريفات الأصوليين على أن الرخصة: "ما استبيح لعذر مع بقاء

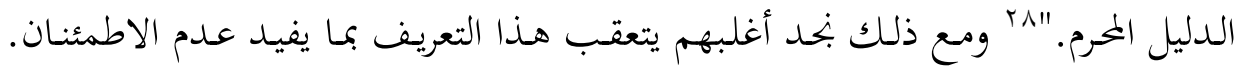
وسبب ذلك أفهم كانوا مقيدين ابتداء بما حدّوا به تعريف العزيمة؛ إذ بسببه بقيت الرخصة عندهم تطلق على ما شرع لعذر شاق، استثناء من أصل كلي يقتضي المنع مع الاقتصار

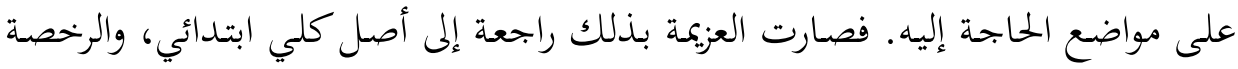
راجعة إلى جزئي مستثنى من ذلك الأصل الكلي. لكوليه

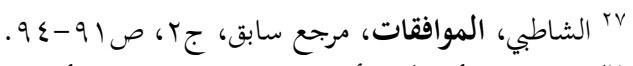

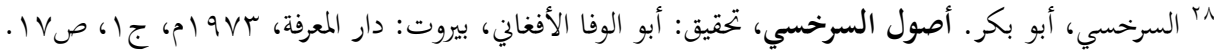


وقـد ردد الشـاطبي وغـيره مـن علمـاء المقاصـد هـذا بوصفه مسـلّماً، متمسـكين فيـه

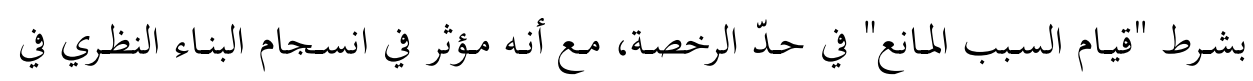

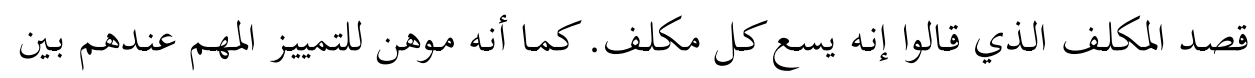

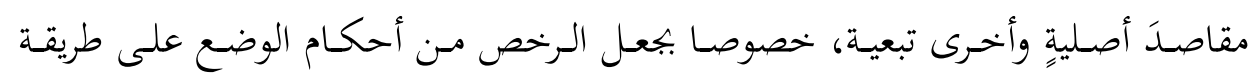
المتكلمين، التي هي طريقة أغلب المقاصديين.

إن إلحاق الأصوليين المتكلمـين الرخصةَ والعزيمة بالأحكام الوضعية فرع عن تصورهم

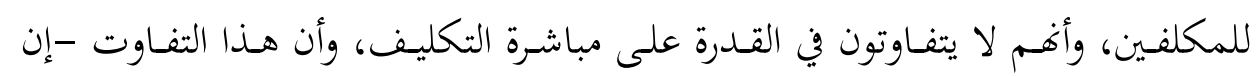

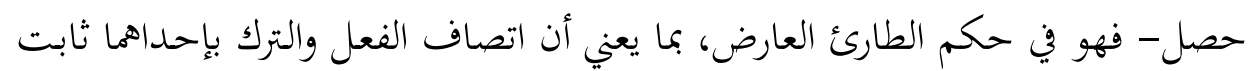

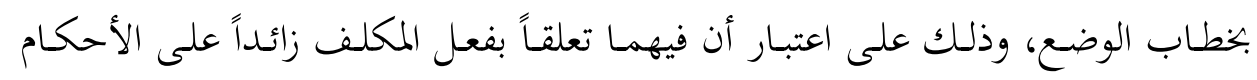
الخمسة.

إن هـذا أمـر لا تشـهد لـه مقاصـد القـرآن؛ إذ يـرد فيهـا مفهومـا الرخصـة والعزيمـة بمـا

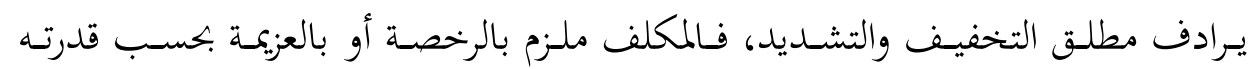

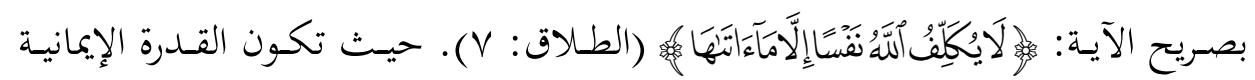

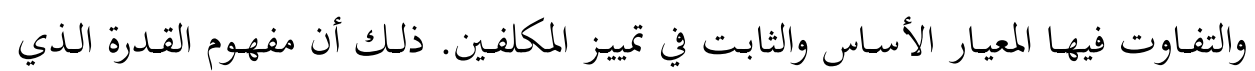
تقدمه يُخرج هذه المباحث من الأحكام الوضعية إلى الأحكام التكليفية.

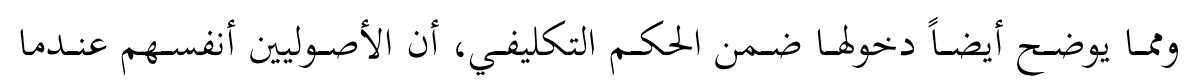

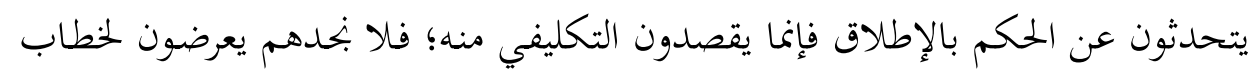

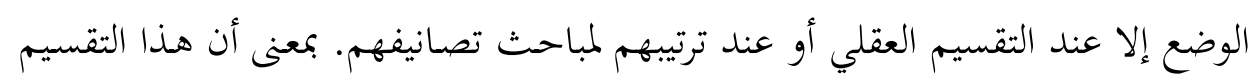

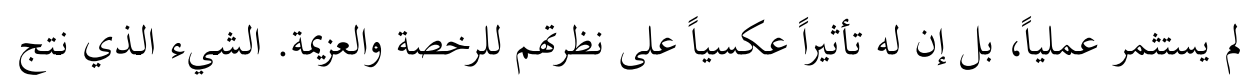

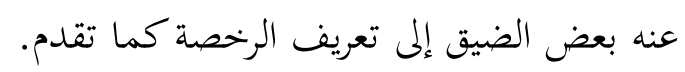

والغالب أن الوقوف على هذا الضيق في حدّ الرخصة هو مـا جعل بعض الأصوليين

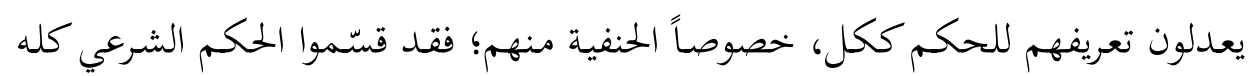

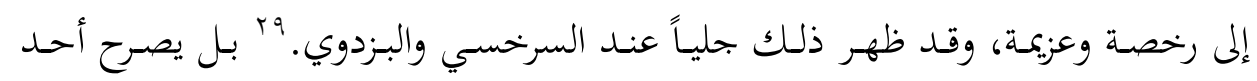


متأخري علماء الأصول وهو الإمام الزركشي بعدم رضاه عن تقسيم الحكمى إلى تكليفي ووضعي، وقال إنه إنما اعتمده متابعة للجمهور .

لكن أقوى تصريح مـا جـاء مـن القرافي قبله، وذلك حسين قال وهـو يتعقب تفسير

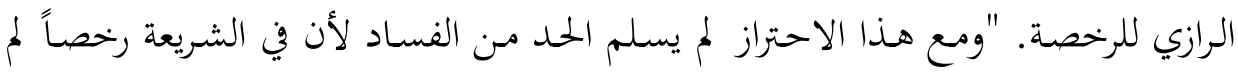

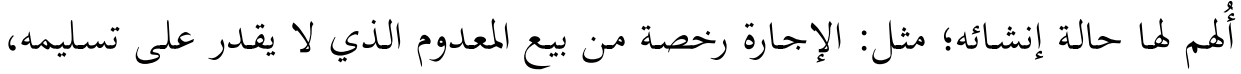

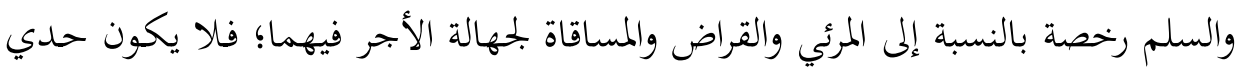

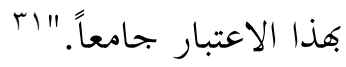

تم خحلص رحمـه الله منصفاً إلى النتيجـة الآتيـة، وهـي مـن روائع الأدلة على التجـرد

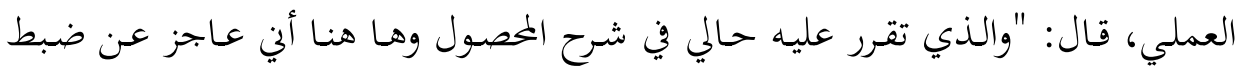
الرخصة بحد جامع مانع، أما جزئيات الرخصة من غير تحديد فلا عسر فيه، إنما الصعوبة بكرية

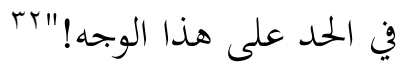

فلعله لا يحتاج إنعام النظر، أن نلحظ الحاجة الملحة هنا إلى ما سبقت الإشارة إليه

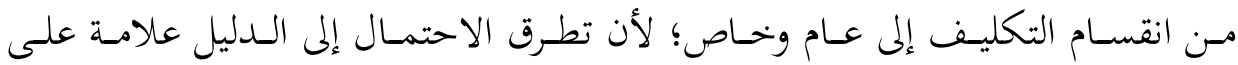
التوسعة فيه، باستنباط حكم الرخصة للضعاف وحكم العزيمة للأقوياء. إعمالاً لمفهوم

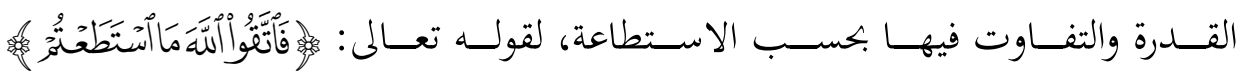

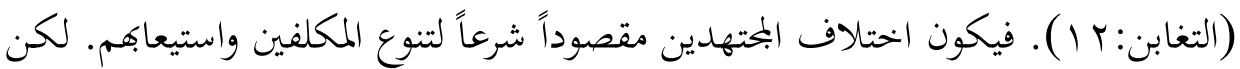
هذه النتيجة ما تزال محتاجة لتأييد.

أول مـن يفيدنا في ذلك تنبّه الشاطبي نفسه إلى ضيق مفهوم الرخصة الأصولي عن

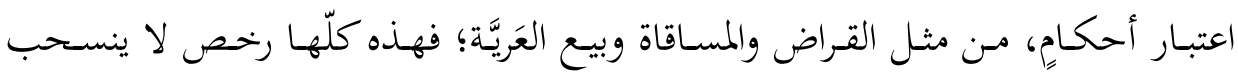
عليها التعريف الأصولي الذي بمقتضاه تزول الرخص بزوال العذر الطارئ، ومع ذلك فهي رخص قارّة باتفاق.

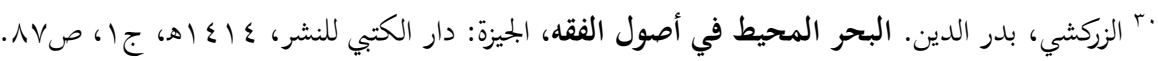

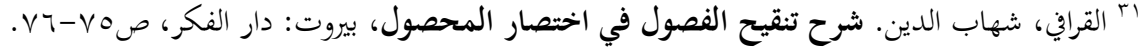

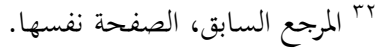


غير أن الشـاطبي لم يَعْدُ أن ينبّهـ إلى ذلك مرة أخرى، وإن حاول تخريج هـذا الحـرج

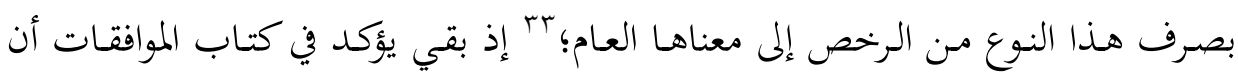
الرخص استثناء من دليل كلي ابتدائي!

ومن المؤيدات أيضاً تنبّه محمد الطاهر بن عاشور عَ الذي لحَظ الفقهاء لا يمثّلون إلا

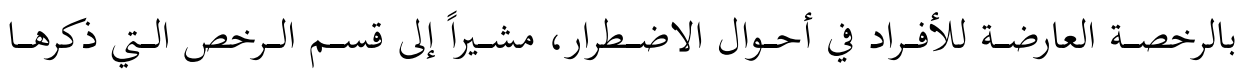

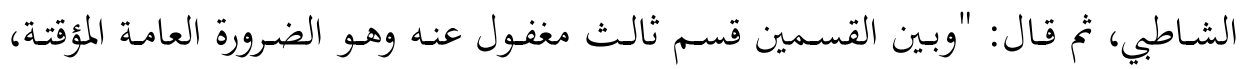
وذلك أن يعرض الاضطرار للأمة أو لطائفة عظيمة منها تستدعي الفعل الممنوع لتحقيق

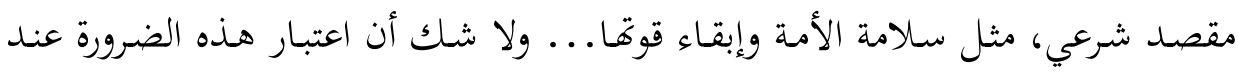

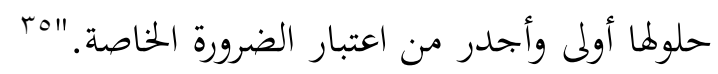

فهـذه على العمـوم، بعضض إشـارات مؤيسدة وغـير مانعـة مـن الشـك في ضسيق الحــد

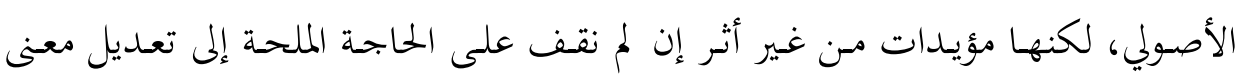

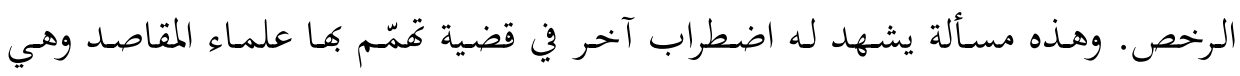
تعيين المكلفين بالواجب الكفائي.

\section{ب. الواجب الكفائي بين أصول مقاصد الشريعة وآفاق مقاصد القرآن:}

إذا كان الواجب الكفائي هو: "كل مهم ديني يراد حصوله، ولا يقصد به عين من

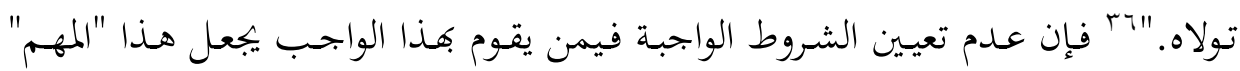

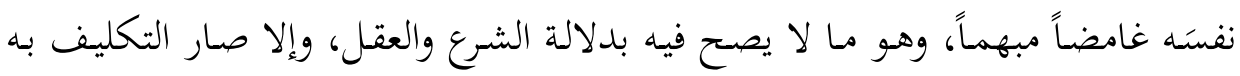
عبثاً.

قال شيخ المقاصد: "طلب الكفاية يقول العلماء بالأصول إنه متوجه على الجميع،

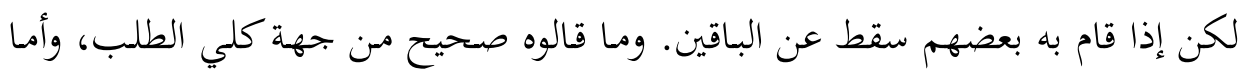

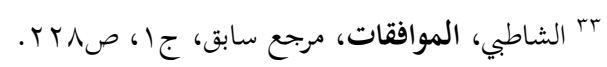

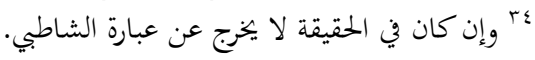

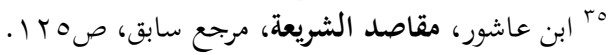

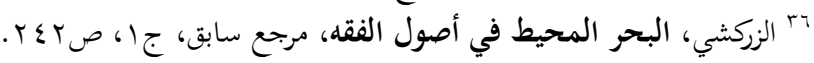




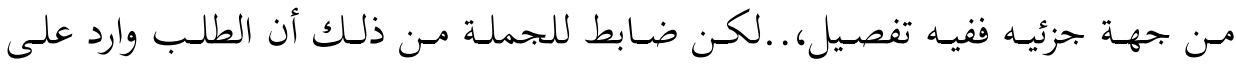

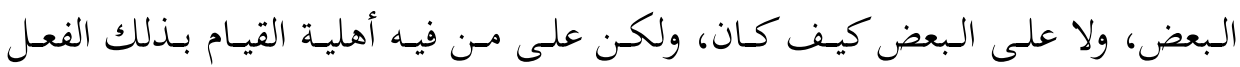

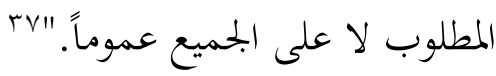

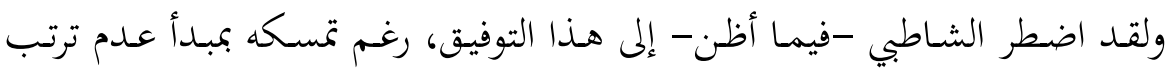

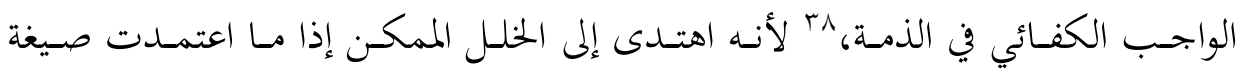

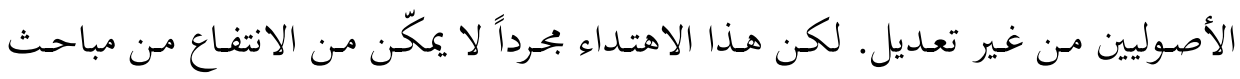

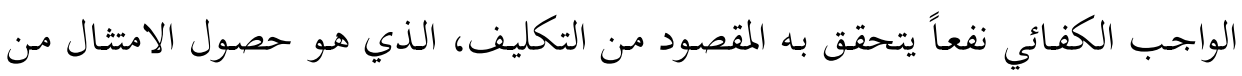

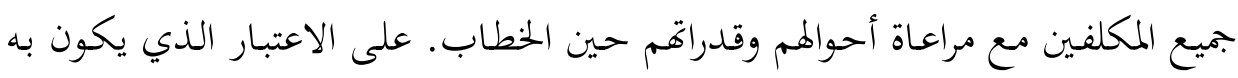

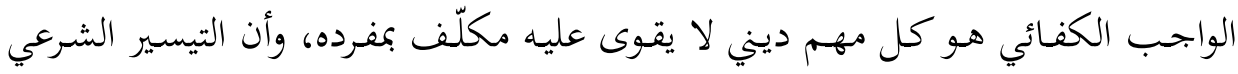
اقتضى أن تكلف به جماعة معينة مخصوصة.

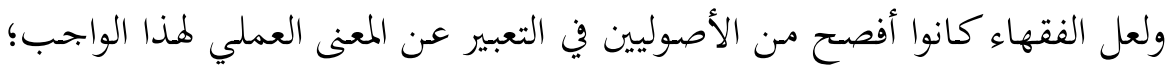

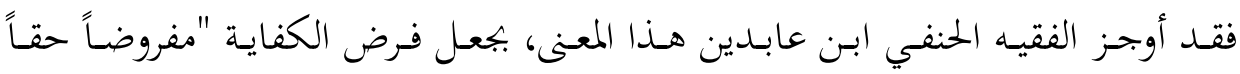

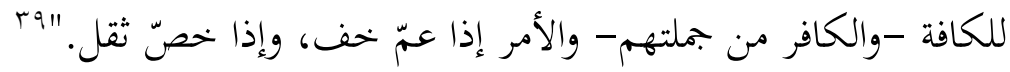
لكن. أمَا من رابط بين توسيع مفهوم الرخصة الذي مر بنّا بشواهده مين القرآن

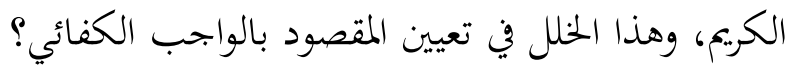
إن محاولات تحرير مفهوم الواجب الكفائي نفسها تستدعي هذا الاعتبار، ذلك أن

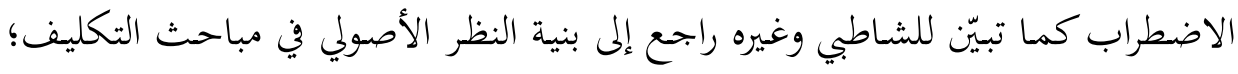

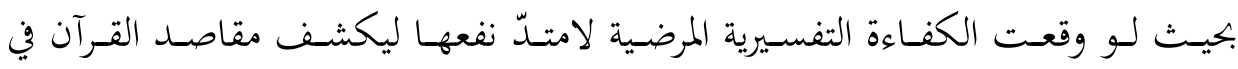

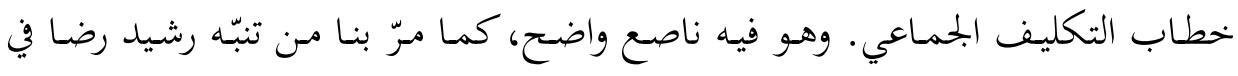
مقاصد القرآن ومن اهتمام محمد الطاهر ابن عاشور به.

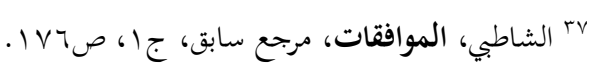

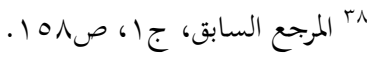

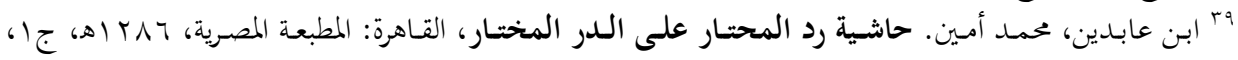




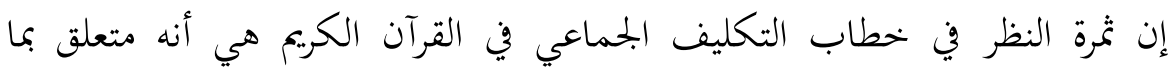

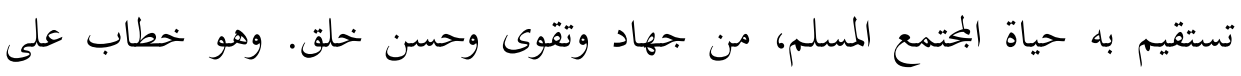

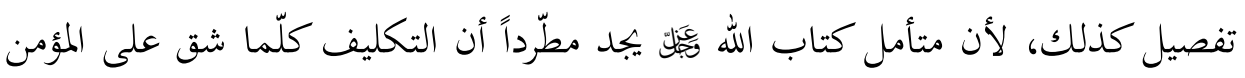

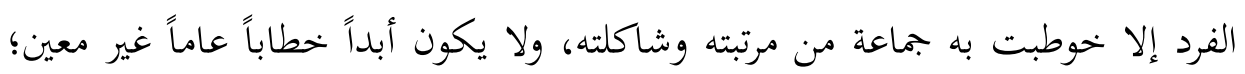

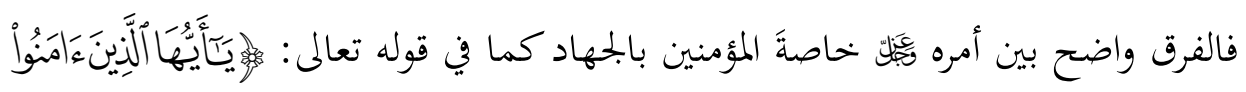

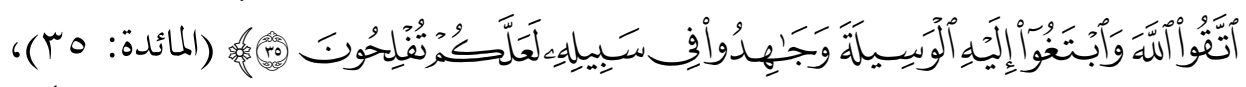

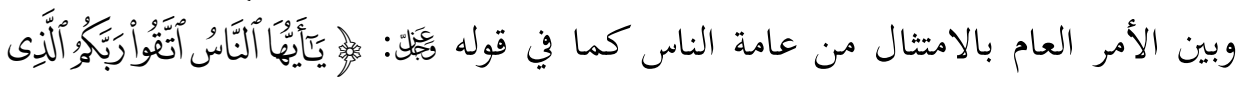

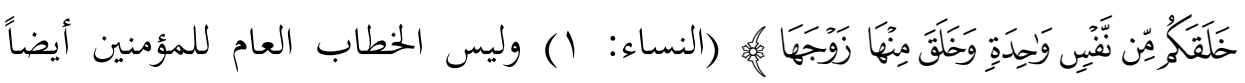

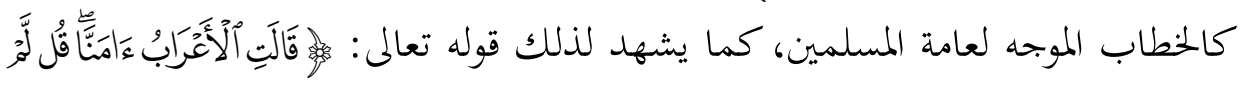

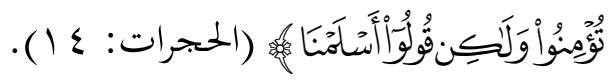

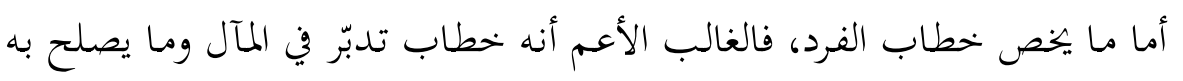

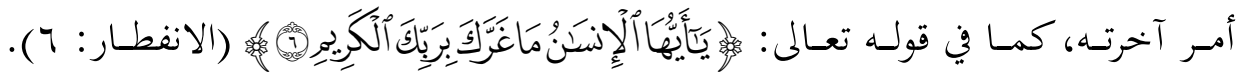

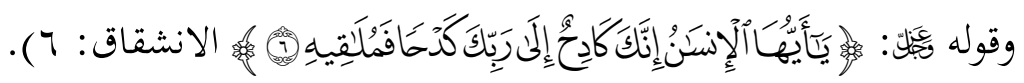

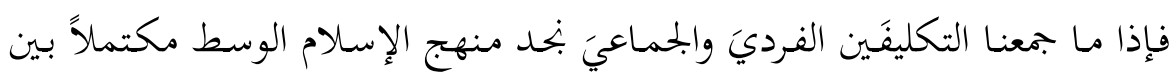

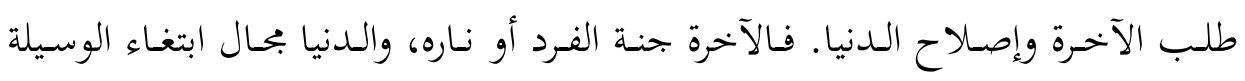
بالانظام الجماعي المتعاون، الذي تعرِف فيه كل جماعة واجبها الإحة الكفائي.

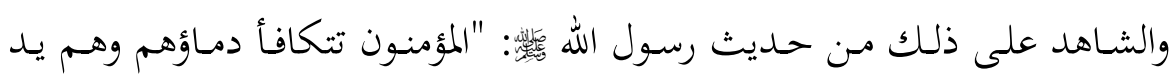

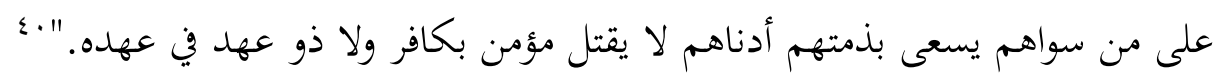

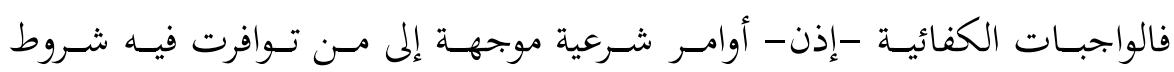

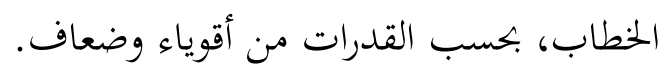

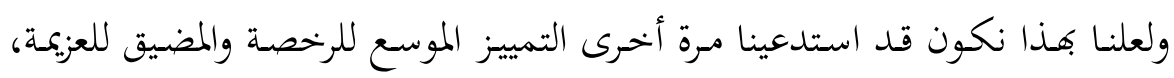

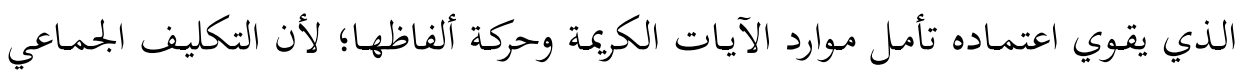
•؛ النسائي، أممد بن شعيب. المجتبي من السنن المشهور بـ"سن النسائي"، دمشق: دار البشائر الإسلامية،

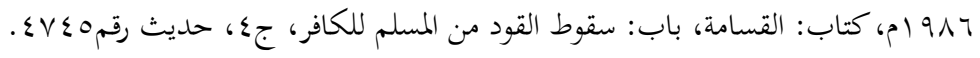


هو تعيين مكلفين مخصوصين للقيام بمهمّ ديني لتوافر شرط ذلك القيام فيهم دون غيرهم. وما هذا الشرط إلا شرط القدرة الذي مرّ بنا آنفاً وأسسنا عليه.

بعد هذه الجولة في أحوال التكليف ومقارنة مـا تتيحه مقاصد القرآن أو على الأقل

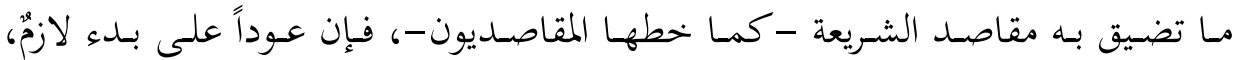

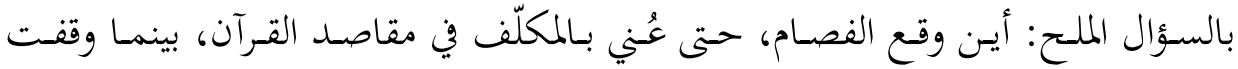

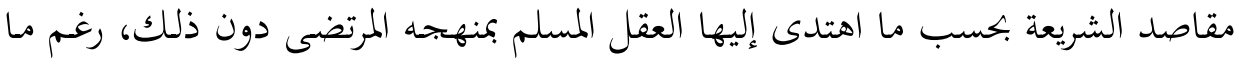
يظهر من متانة صرح البناء النظري الذي انطلق منه؟

\section{ثالثاً: محاولة في تعليل ضيق التكليف في مقاصد الشريعة}

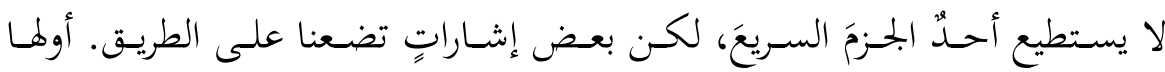

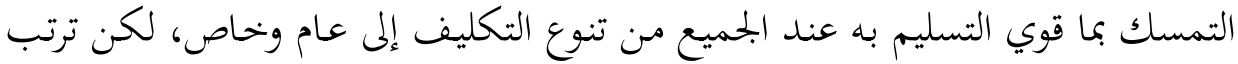

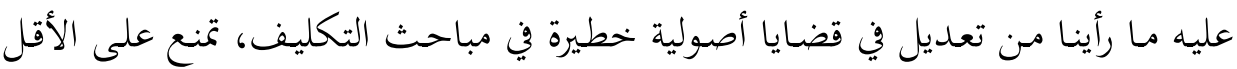

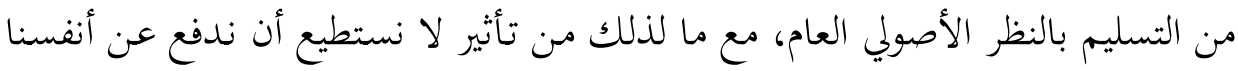

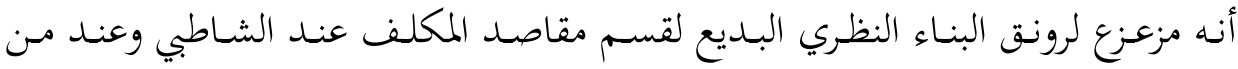

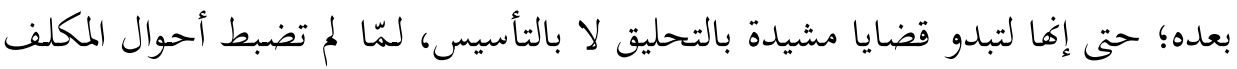

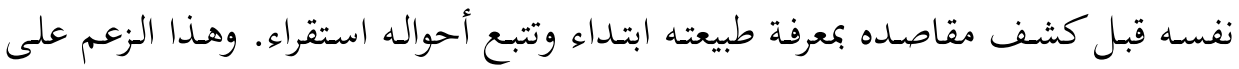

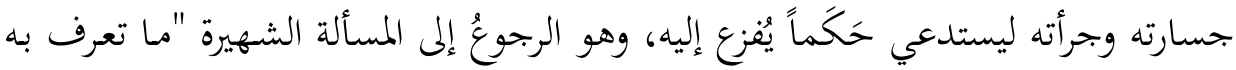

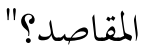

نشير بعض إشارات عجلى إلى القضية، لكن نقدم لها بتوطئة في ثمرة الظنون بالمتاح من النظر في آي الكتاب البحيد مقارنة بأصل النظر عند الأصوليين.

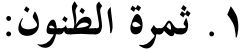

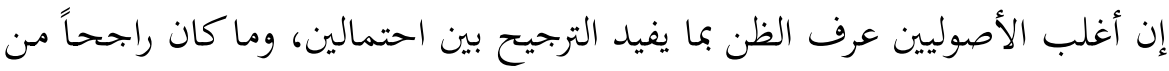

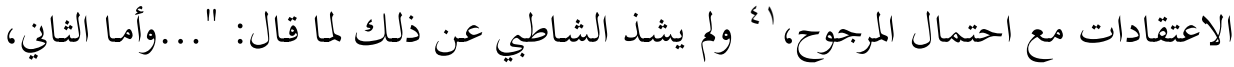


وهو الظني الراجع إلى أصل قطعي فإعماله أيضا ظاهر، وعليه عامة إعمال أخبار الآحاد،

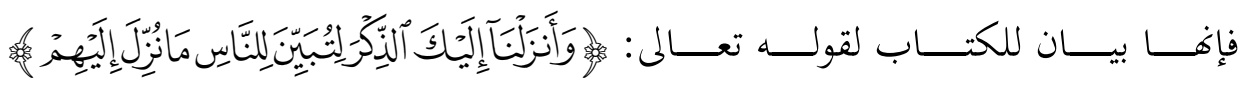

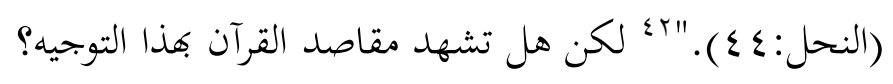

لنعد إلى المفسرين الحسائمين حول مقاصد القرآن دون أن يواقعوها. وهو عَوْد ليس

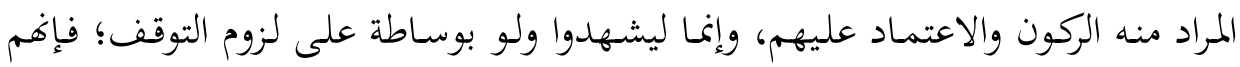

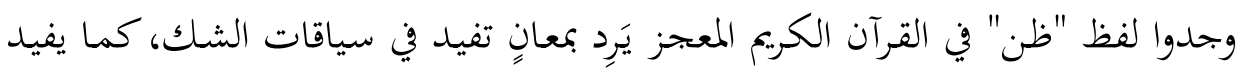

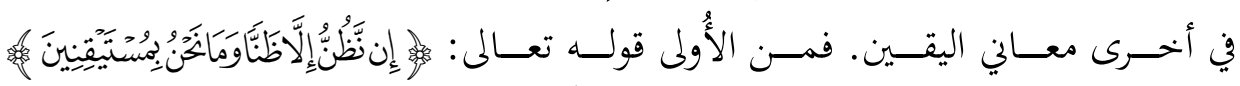

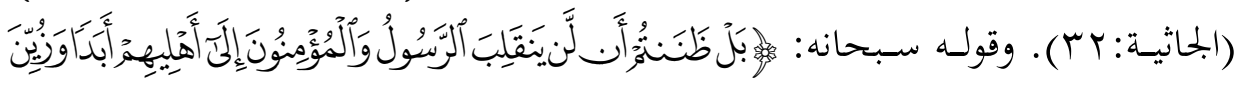

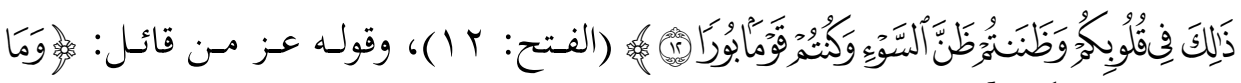

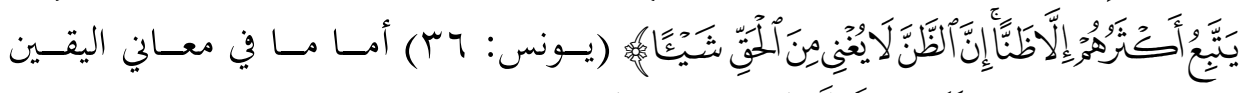

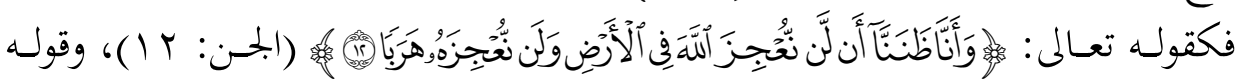

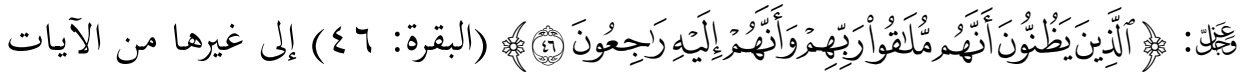
التي توقف على هذا التنوع في معاني الظن في القرآن الكريم. وهـو تنويـع يـدفع ثانيـة إلى تعقـب حـدّ الظـ؛ إذ ليس في معانيـه الواردة في القـرآن

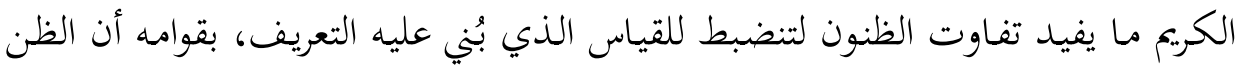

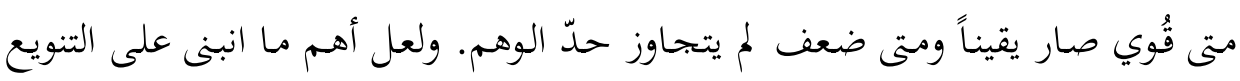

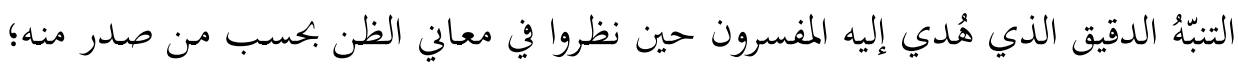

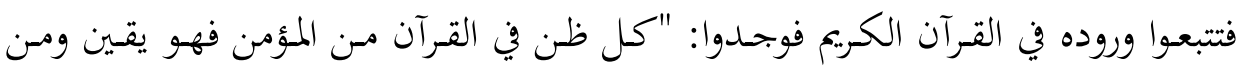

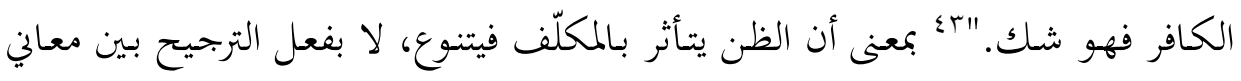
اليقين أو الشك، وإنما يكون شكاً أو يقيناً بحسب الظّان.

- البصري، أبو الحسين. المعتمد في أصول الفقه، تحقيق: خليل الميس، بيروت: دار الكتب العلمية، ب. مـ اهـ،

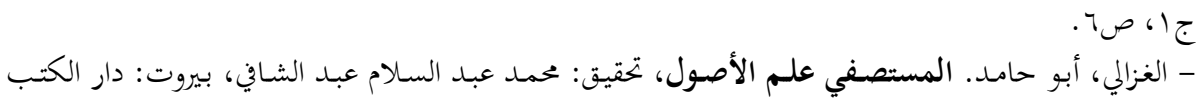

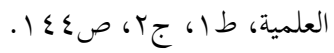

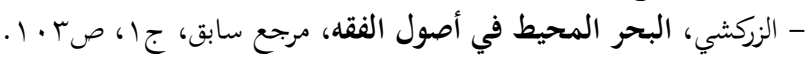

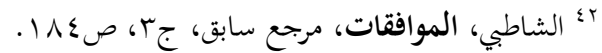

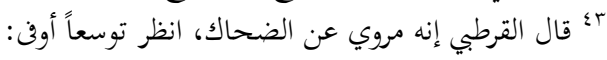


وهذه مسألة تبدو في غاية الأهمية لفهم مصدر الخلاف في تعريف الظن؛ لأن تنبيه

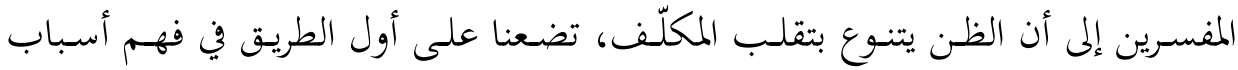
الحرج الذي حاول الأصوليون تفاديه.

ويسند ما تقدم أن للمفسرين تحرراً في النظر زائداً على ما بمقدور الأصوليين؛ إذ لم

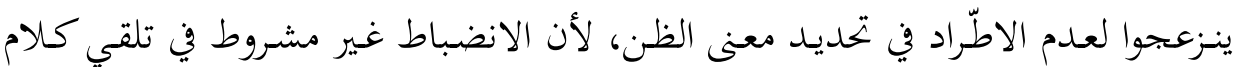

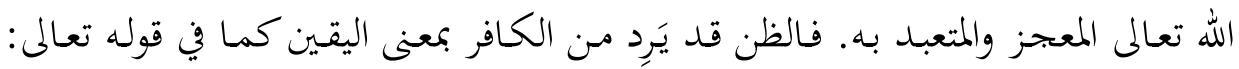

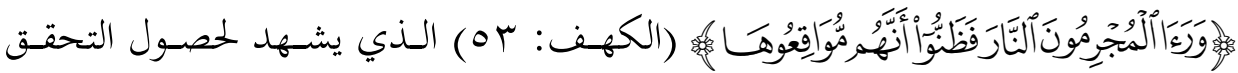
من الكافر في هذا السياق، لكن تبقى مع ذلك القاعدة منسجمة، والطمأنينة لهذا المعنى

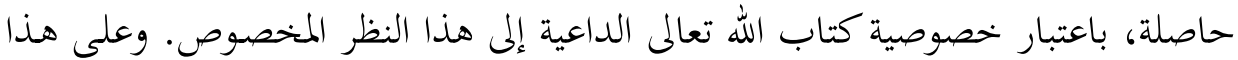

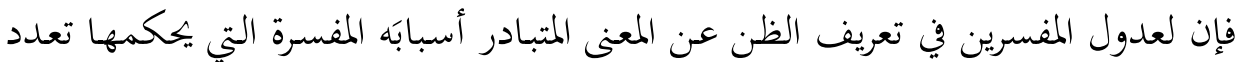
وروده في القرآن الكريم.

فالظنون إذن توسعة مقصودة لاعتبار المكلف واستيعاب أحواله بالخطاب، فيكون

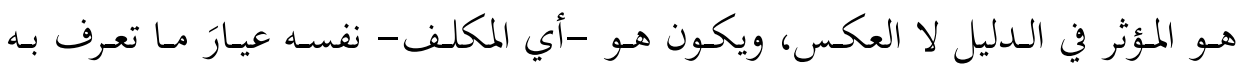
المقاصد.

\section{Y. الاضطراب فيما تعرف به المقاصد الأصلية:}

المبـدأ السـليم للمسـألة مـا تقرر في البنـاء النظري مـن أن المقاصد هي قصد الشـارع

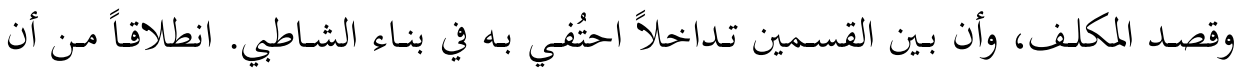

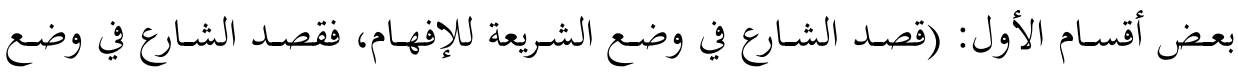

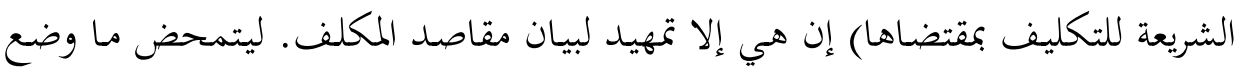

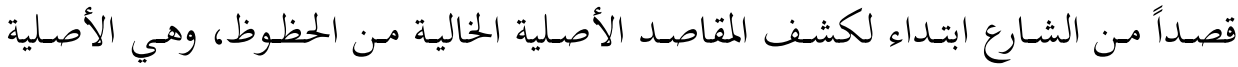
القطعية التي تواترت على إثباتها طائفة عظمى من الأدلة والنصوص، فلا تحتمل تأويلاً،

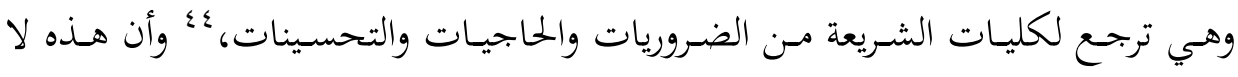
- القرطبي، أبو عبد الله محمد. الجامع لأحكام القرآن، القاهرة: الميئة المصرية العامة للكتاب، ط؟، 9V1 (م)، 


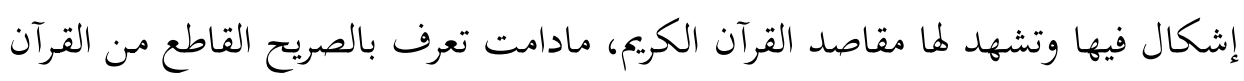

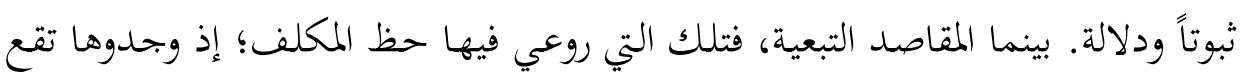

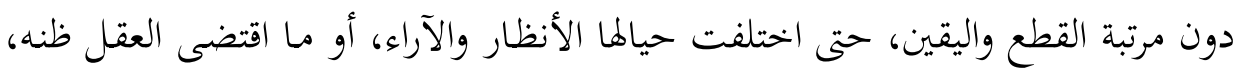
أو دلّ عليه دليل ظني.

بمعنى أن منتهى مـا تعرف به المقاصد هو نظرٌ متجردٌ في الدليل الشرعي، وأن هذا

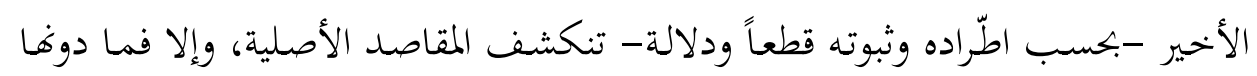
ظنيةٌ، للمكلف فيها حظ.

\section{- شواهد من الاضطراب:}

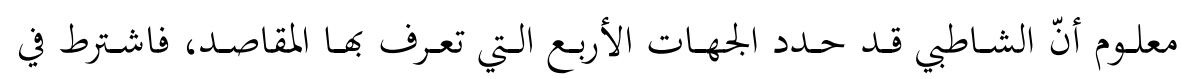

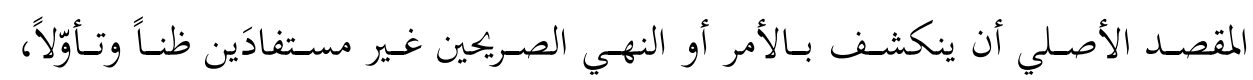

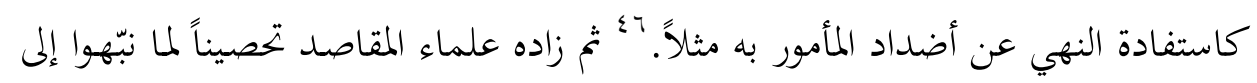

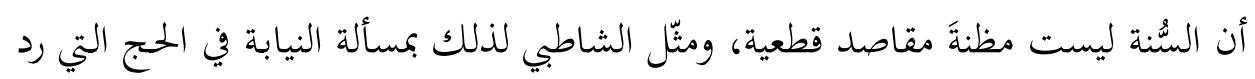

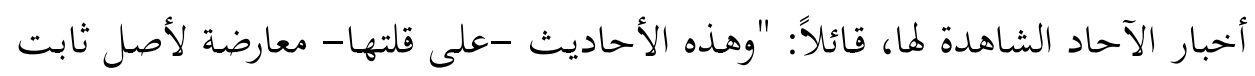

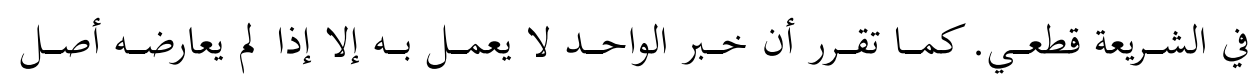

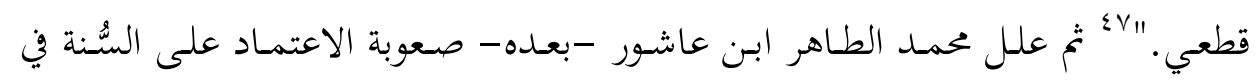

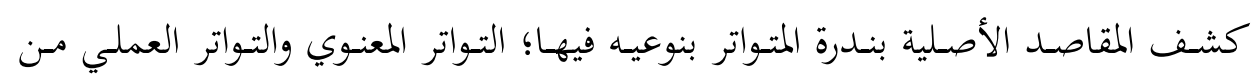

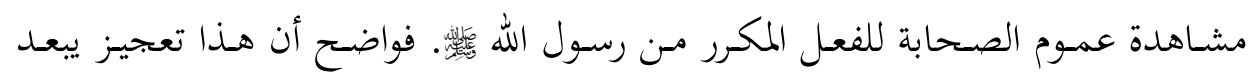

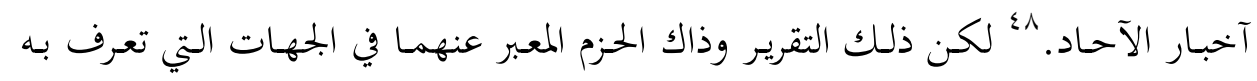

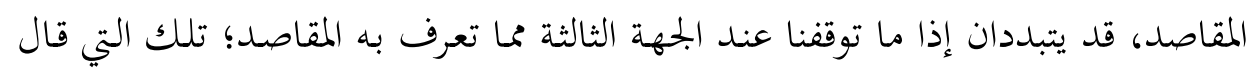

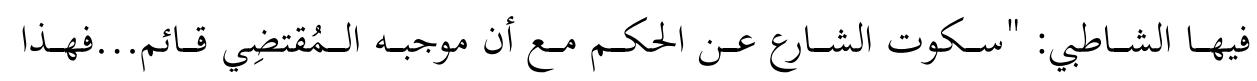

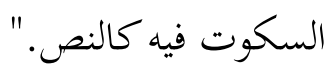

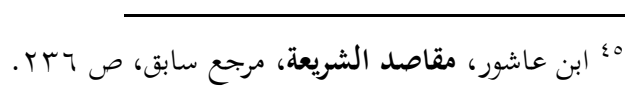

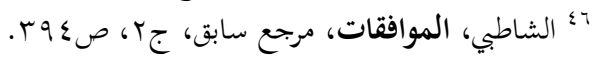

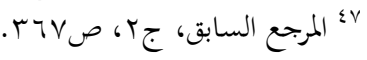

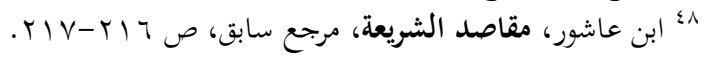


فغير خفي هنـا أنه عـاد بـالنقض على الأصل الأول، الذي هو بحرد الأمر والنهي الصريحين؛ إذ كيف يستقرأ سكوت الشارع مع توافر داعي البيان والتشريع؟ وكيف يكون

$$
\text { نصاً وهو سكوت؟ الصنين إد }
$$

إن مما يزيـد الريبة أنْ ربط ابن عاشور أيضـاً بهـهـ الجههة سبب تنوع المقاصـد، وأن

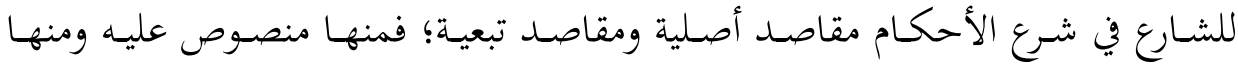

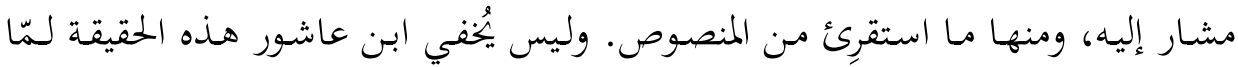

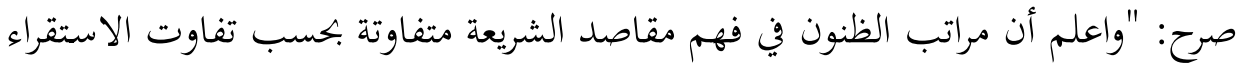

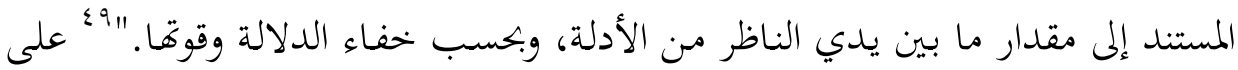

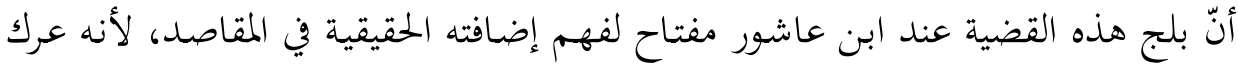

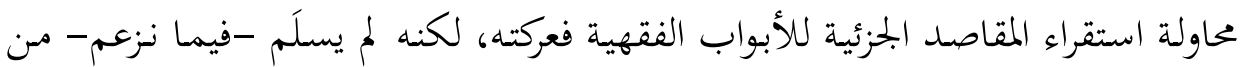

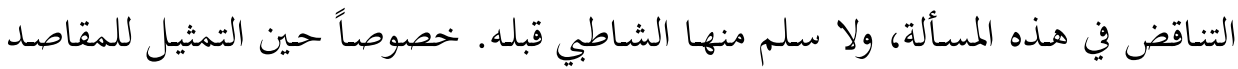

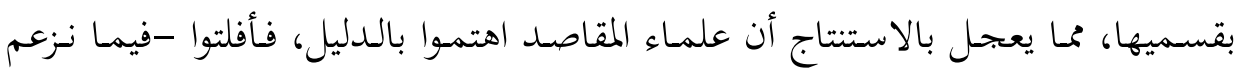

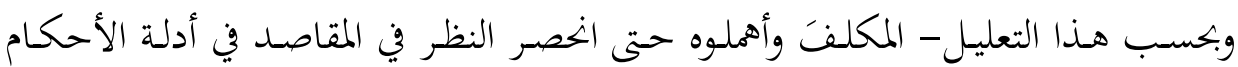

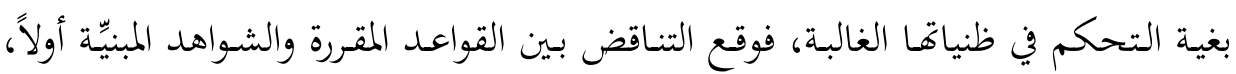
قبل التنزيل عملاًا.

ومن أمثلة ذلك، أننا إذا سلّمنا بالقاعدة في المقاصد التبعية "أن الخحلاف فيها ممكن مسلّمّ" بسبب اختلاف المدارك في الظنون كما عللوا، فإننا لانعدم اضطراباً في التمثيل للمقاصد الأصلية نفسها، تلك التي نظن جميعا أها سهلة الكشف لتواترها واطرّاد علتها. فلقد تقدم كيف أن الشاطبي وابن عاشور بعده قد جعلوا السُّنة غير مؤهلة للمقاصد

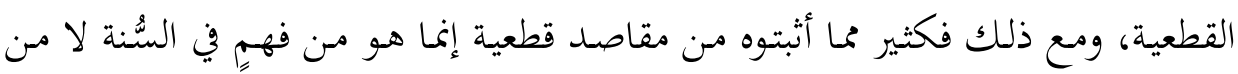

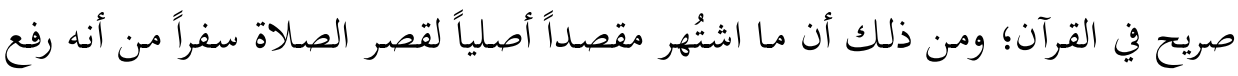

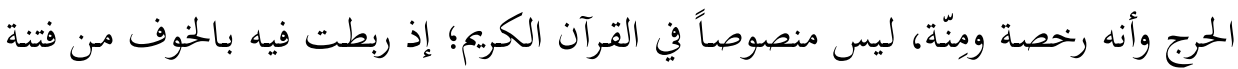

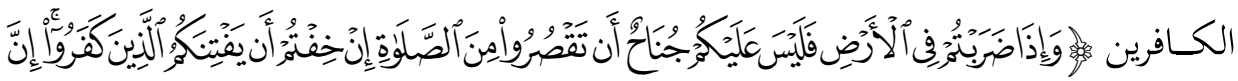

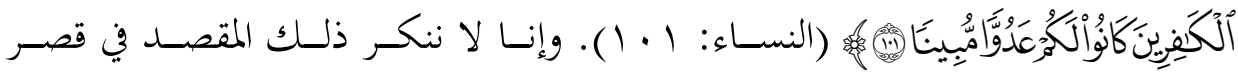


الصلاة، لكنه يعسر علينا إرجاع كشفه بما قال المقاصديون إلى الصريح من القرآن، بينما هو من السُنة الظنية من غير إنعام نظر ولا كثير تأمل. . مثالٌ آخر أوضح في بيان المفارقة بين التنظير والتنزيل لهذه المقاصد القطعية؛ وهو ما

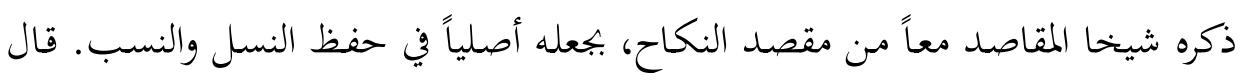

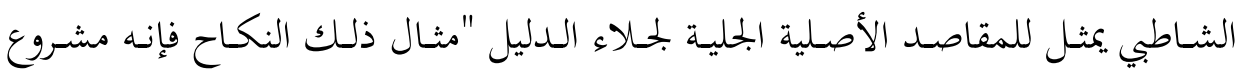

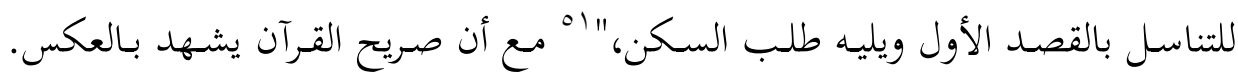

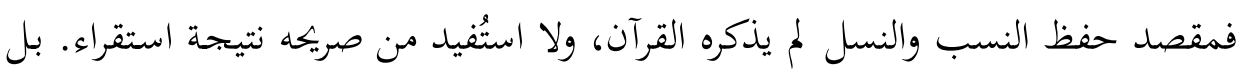

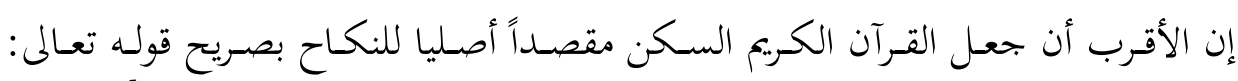
وَهَ

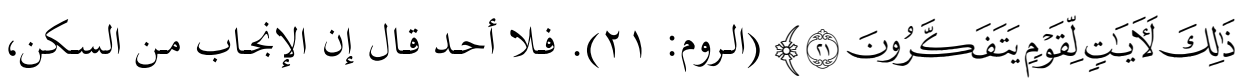

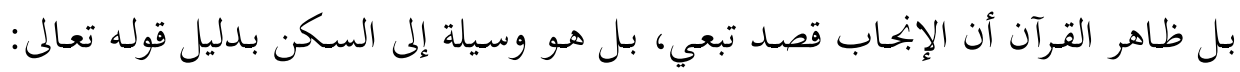

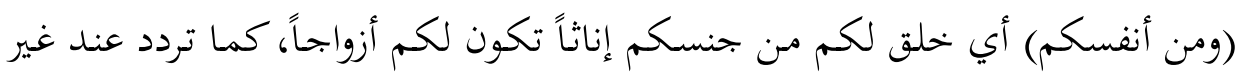

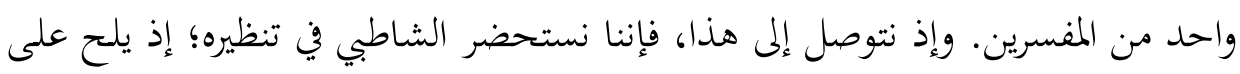

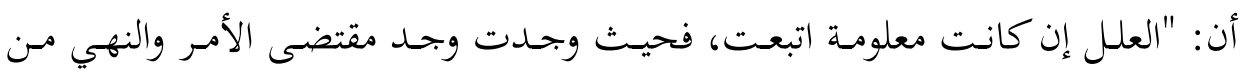
القصد وعدمه.... وإن كانت غير معلومة فلا بـد من التوقف عن القطع على الشارع أنه وحنه قصد كذا وكذا. " ق وعده."

ولسنا بجد عند ابن عاشور أيضاً غير هذا التوجيه لمقصد النكاح، وإن بدا متعقباً،

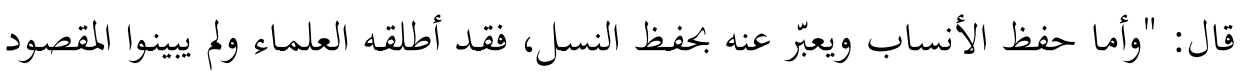

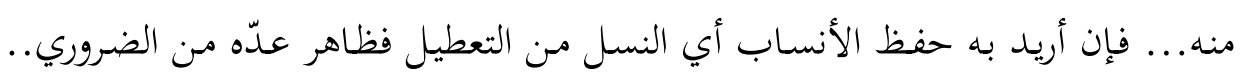

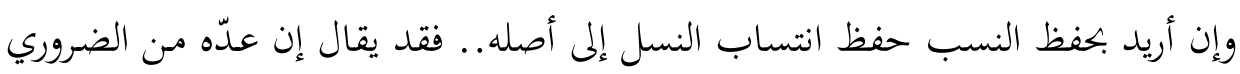

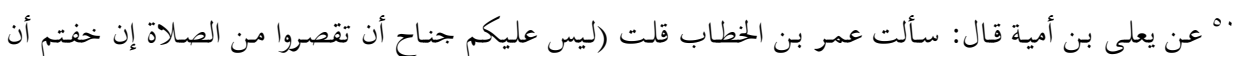

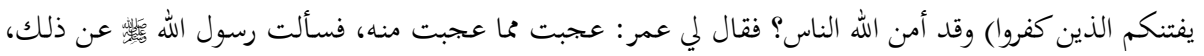

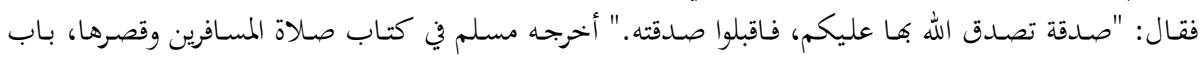

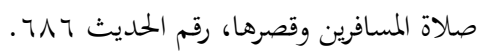

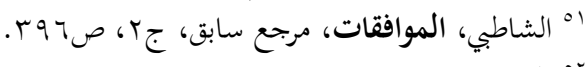

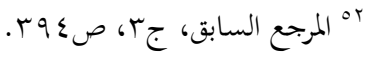




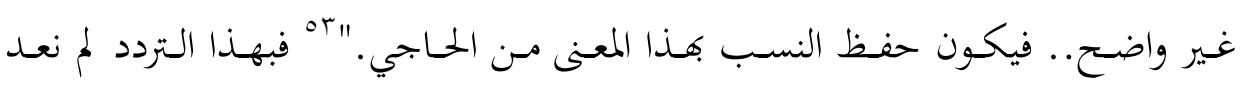
نستطيع القطع أيهما الأصلي وأيهما التبعي، لكن لا يخفى في ذلك تأثير خحبر الآحساد

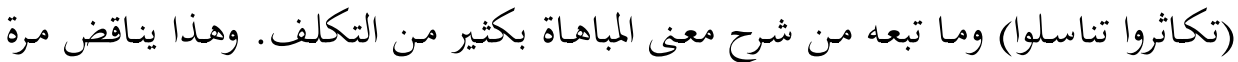
أخرى ما سطروه في طرق معرفة المقاصد.

فلا شيء منضبط إذن، حتى فيما ظن قطعياً سهالًا لا خهلاف فيه. والأبعد في ذلك أنه يشكك في القوائم التي أقيم عليها بناء ما تعرف به المقاصد. فعلى أي استقراء وقفوا؟

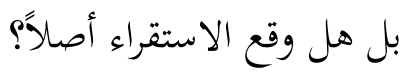

\section{- مبيعة الاستقراء المقاصدي:}

مـا مـن شـك في أن تقسيم المقاصـد مبني على اسـتقراء، لكننـا لا نظنه الاستقراء

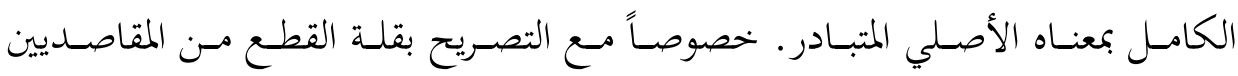
أنفسهم، وإن رهنوا به المقاصد الأصلية القطعية؛ فما هو إلا استقراء كلي وليس عامّاً. يدفع إلى هذا الظن أن شيخ المقاصد لمُ يجعل الاستقراء مما تعرف به المقاصد، وإن

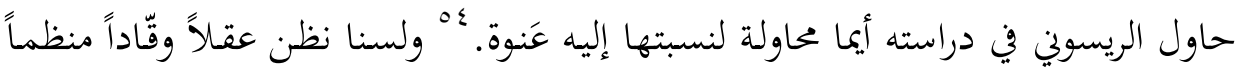

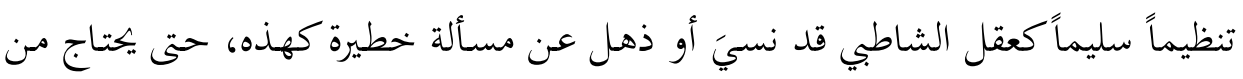
يكملها له أو يعتذر له.

إن الشـاطبي قاصد فيمـا نعتقـد ألا يـدعي كشف المقاصـد بالاستقراء، فهو القائل:

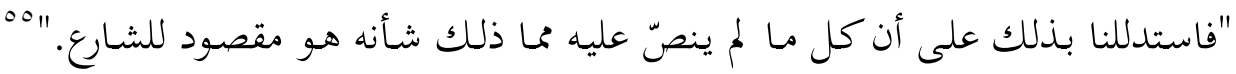

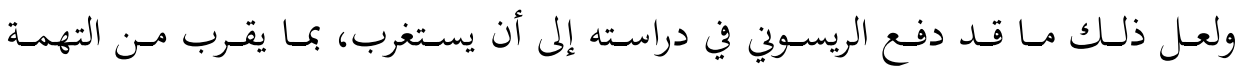
بالتناقض، بين جمع الشاطبي لاعتبار الظنون الغالبة جهةً لمعرفة المقاصد، واشتراط الصريح من الأمر والنهي غير المستفادَين في المقاصد القطعية.

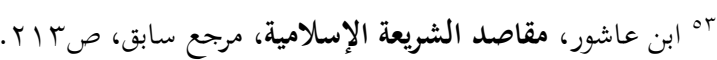

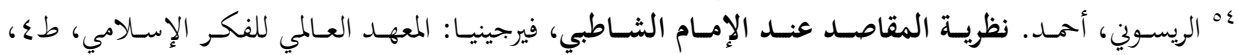

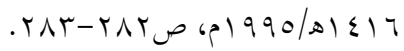

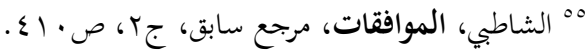


أما ابن عاشور فقد نص صراحة على أن الاستقراء جهة لمعرفة المقاصد. وهو تصريح

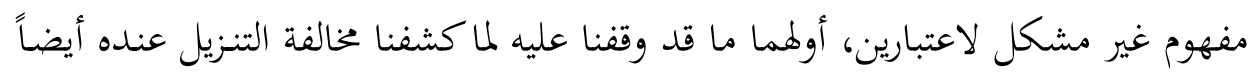
للتنظير، والثاني أن ابن عاشور قد رام في مشروع لاحق استقراء القواعد الكلية للأبواب

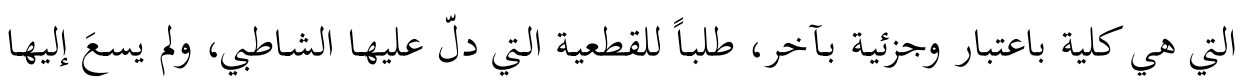

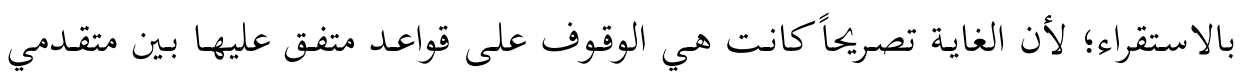

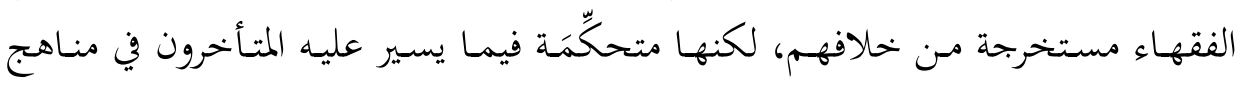

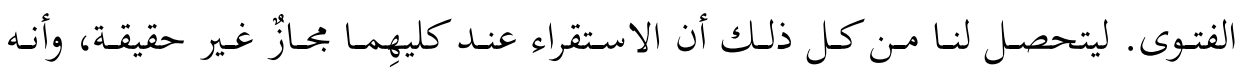
استقراء بالواسطة.

وهي نتيجةٌ، الوصولُ إليها يشككك في كثير مما اشتهر من استفادة الشاطبي ومسن

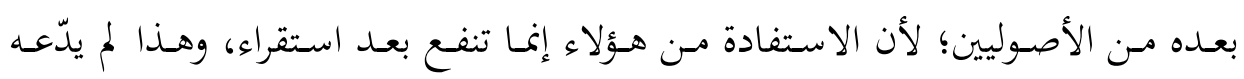

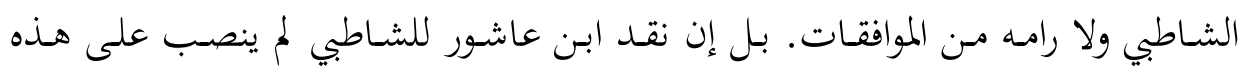

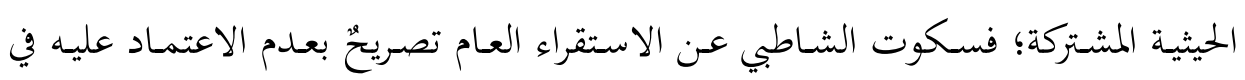

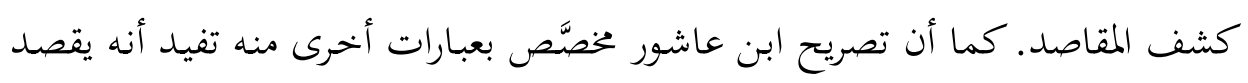
الاستقراء الكلي لا الحقيقي؛ فكثيراً ما يقول إني لا أقصد ما قصده الأصوليون. وعلى كل ذلك. فإنه لكلامٌ دقيقُ يستحق التوقف عنده، ما ذكره محمد الفاضل ابن

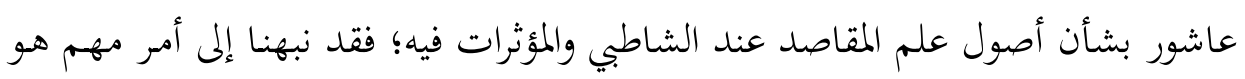

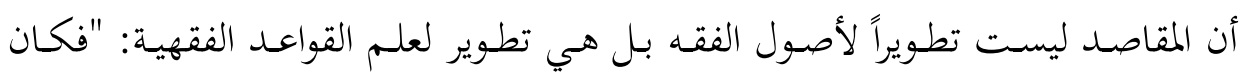

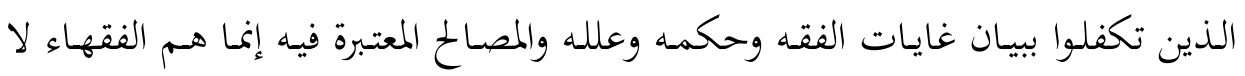

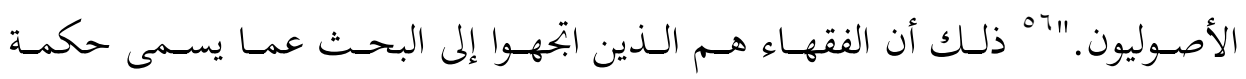

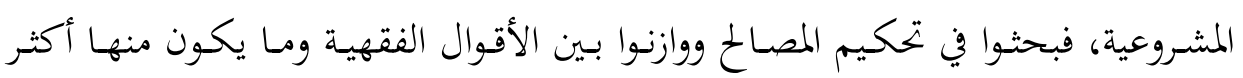
تحقيقاً للمصالح. ويدفعنا لاعتبـار هـذا القـول إن النتيجـة التي وقفنـا عليها مـن تعذر الاستقراء بمعناه الحقيقي تلائم هذا التحليل من جهتين: 
الأولى: طبيعة علم القواعد نفسه؛ فمجاله التغليب. فليس يمانع في الاستقراء الكلي

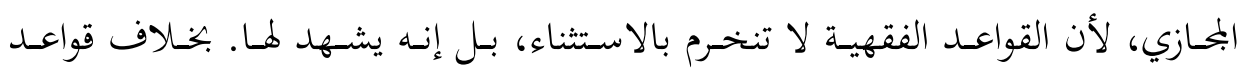

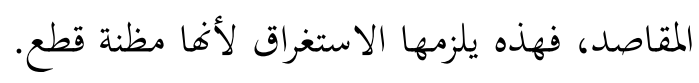
والثانية: إن شيوخ الشاطبي الثابتين في ترجمته هم علماء القواعد وليس علماء أصول الفقه. بـل إن الشيخ الذي لزمه الشـاطبي هو أبو عبـد الله المقّري، وهـو الذي سمـا بعلم الأصول القريبة -القواعد الفقهية-، فأفصح أن غرضه من كتابه البديع في القواعد تأصيل مبادئ كلية لا اختلاف فيها بين المذاهب، وأن يستخرج بالتبعية من تلك المبادئ الكلية

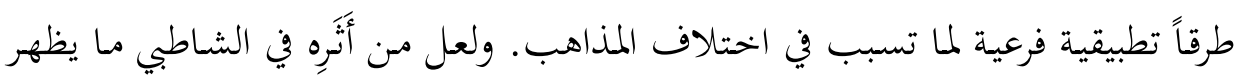
لكلِّ مَن تأمل مقدمة الكتابين من تماثل غايات التأليف لديهما. ولعل الشاطبي هو العالم الفتّاح الذي رجاه الونشريسي لكتاب المقّري، فيما حكاه عنه صاحب نيل الابتهاج:

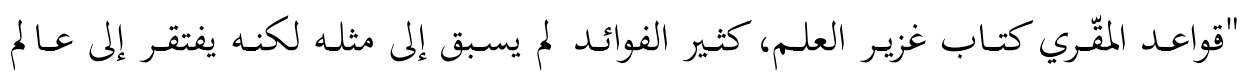
فتّاح

ومهم يكـن مس أمرِ، فهذه قضية أخرى أكتفي منها بوجـه الشـاهد في قضيتنا في التكليف، على أن مقاصد القرآن تلحّ علينا أن نتحرر من قيود مقاصد الشريعة المتشبثة بمقولاتٍ قمل المكلف، بسبب الشغف بحلم الخروج بالرأي الواحد الذي لا يختلف فيه فيه

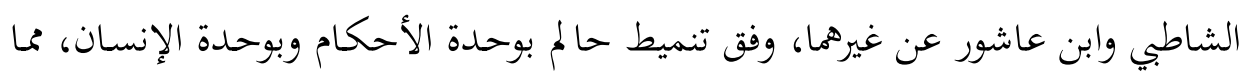

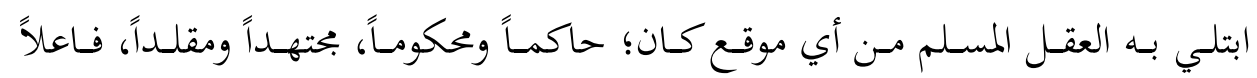

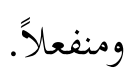

فشتّان بين تلك المقاصد، وآفاق مقاصد القرآن الكريم، بالاعتبـار الحضاري الذي

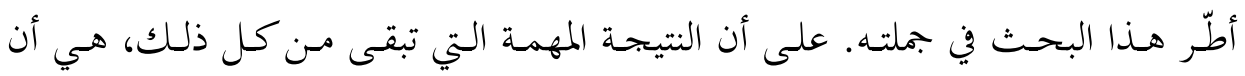
الاهتمام بمقاصد القرآن قد يفتح آفاق من إعادة تشكيل العقل المسلم في فعله الحضاري الذي طالما ظنه أساساً بينما هو بجرد نتاج ومظهر.

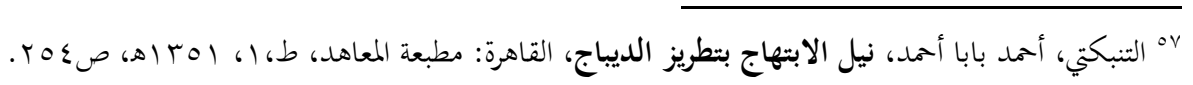


خاتمة:

وين الخنـام، إن هـذا البحـث -بـالرغم مـن كـل ذلك السـجال - لا يـروم التقصّي والتحقيق ولا الهدم والتشكيك، بقدر ما يأمل أن يدل دلالة جديدة على طرئ طريق رصينة في

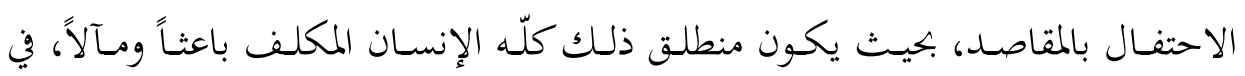

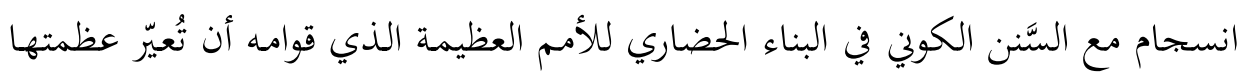
بمدى حركة الفاعل الإنسان.

وإن المداخل السليم لذلك هو استثمار الإذن العام في تـبر القرآن الكريم من غير

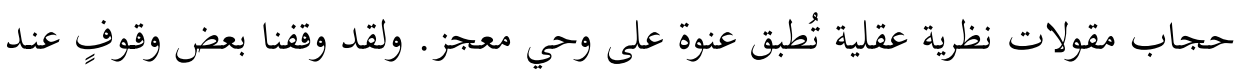

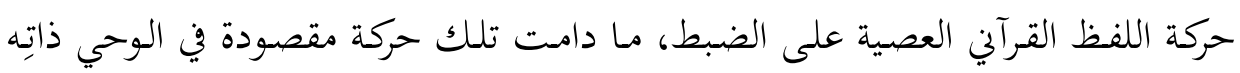

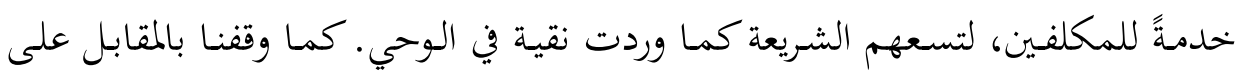
عسر وصعوبة انطباق القواعد التي وإن توصل إليها النظر الأصولي بكفاءة عالية، إلا أها ليست تسمو دائماً لاستيعاب كل خطاب التكليف في الوحي. فيُستفاد من ذلك النظر السامي، لكن دون الركون إليه كلية.

ولقد مُثنل لذلك بجملة مباحث في التكليف، أولها كيف يقع الاضطراب ابتداء في

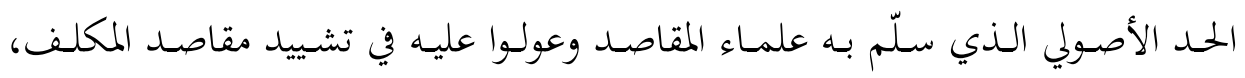

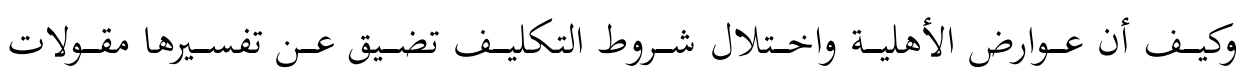

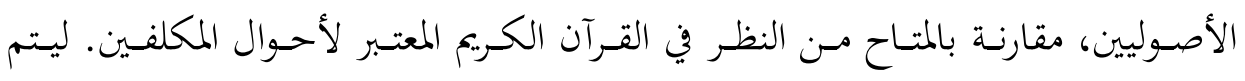

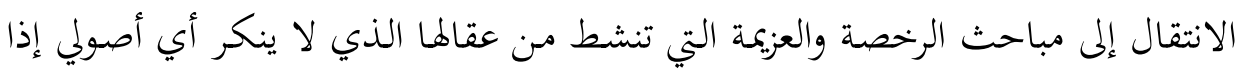
ما اعتبر المكلف ابتداء قبل مقاصده. ولعل سنام ذلك التمثيل قد حصل بقضية تلعية تعيين

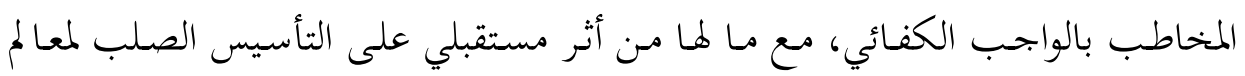

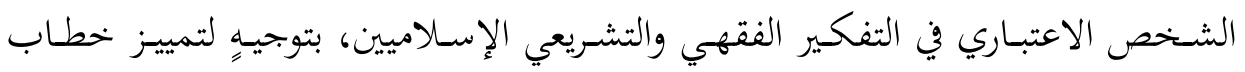
الجماعة من خطاب الفرد.

وتسوج البحـثث ختامـاً، بمحساولتين في بيـان حاجـة علـم المقاصــ لتعـديل مباحـث التكليف وفق المتبادر من مقاصد القرآن من غير تكلّف؛ الأولى في استثمار الظنية الغالبة 
في القرآن الكريم وفي كل دليل شرعي، بـدل التعرض لها بالترجيح والتغليب؛ والثانية في

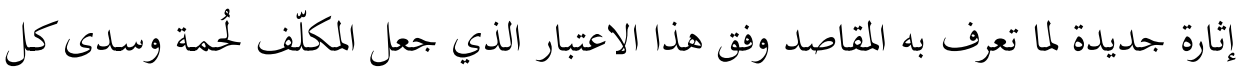

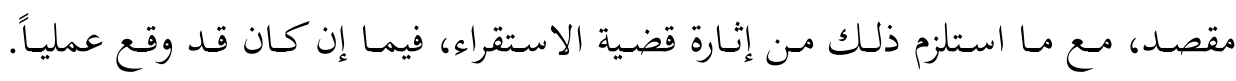
خصوصاً بالوقوف على أمثلة يوردها الشاطبي وابن عاشور للمقاصد القطعية لم يتضح منها الانضباط لقواعد المقاصد، ليترجح أن لذلك الاستقراء معنى آخر يفتح باباً جديداً لأسئلة أخرى في بكوث قادمة. 